\section{EMERGING NEED FOR MICRO-CLIMATIC CONSIDERATIONS IN URBAN DESIGN PROCESS: A REVIEW}

\author{
Mohammadhassan Salmanian*, Norsidah Ujang \\ Faculty of Design and Architecture, Universiti Putra \\ Malaysia, 43400 Serdang, Malaysia
}

Article history

Received

22 October 2020

Received in revised form

24 October 2021

Accepted

7 November 2021

Published Online

20 December 2021

*Corresponding author

gs57464@student.upm.edu.my

\section{Graphical abstract}

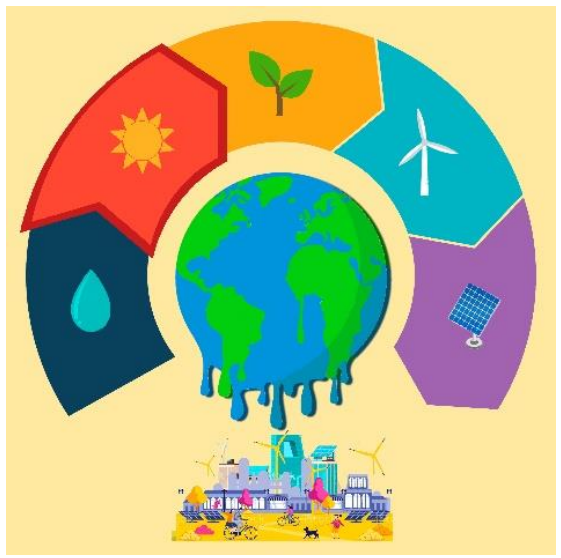

\begin{abstract}
The effects and consequences of climate change have been extensively considered in the urban design qualities. The climatic factors directly affect human activities in urban spaces, particularly in the pedestrian environment. The global issues on climate change could be well understood by understanding the contributions of climatic conditions towards thermal environmental discomforts. So, the roles and processes in urban design can be enhanced to reduce the impacts of extreme urban climate on pedestrian experiences. This current article focused on the systematic review of thermal comfort through urban designing, detailing the objectives, methods used, and the body of knowledge to deal with this issue. This paper also summarizes the current understanding and challenges in addressing the microclimatic analysis roles in human life by discussing the thermal comfort studies and literature regarding human, building, and city levels. Finally, this systemic study demonstrated the needs and potential assessments based on the quality and standardization of human-centric data collection and interpretation. It specifically addressed an urban planner's structure that could be used as an empirical method during the urban planning processes. In conclusion, the applications of the recommended methods identified in this study aid in the design decisions to shift towards climate comfort in urban spaces.
\end{abstract}

Keywords: Climate change, Urban climate, Climatic comfort, Urban space, Pedestrian environment

\begin{abstract}
Abstrak
Kesan dan akibat perubahan iklim telah banyak dipertimbangkan dalam kualiti reka bentuk bandar. Faktor iklim secara langsung mempengaruhi aktiviti manusia di ruang bandar, terutama di persekitaran pejalan kaki. Isu-isu global mengenai perubahan iklim dapat dipahami dengan baik dengan memahami sumbangan keadaan iklim terhadap ketidakselesaan persekitaran terma. Oleh itu, peranan dan proses dalam reka bentuk bandar dapat ditingkatkan untuk mengurangkan kesan iklim bandar yang melampau terhadap pengalaman pejalan kaki. Artikel terkini ini memfokuskan pada tinjauan sistematik mengenai keselesaan termal melalui perancangan bandar, diikuti dengan perincian objektif, kaedah yang digunakan, dan badan pengetahuan untuk menangani masalah ini. Makalah ini juga merangkum pemahaman dan tantangan terkini dalam menangani peranan analisis mikroklimatik dalam kehidupan manusia dengan membincangkan kajian dan literatur keselesaan termal mengenai tahap manusia, bangunan, dan kota. Akhirnya, kajian sistemik ini menunjukkan keperluan dan penilaian berpotensi berdasarkan kualiti dan standardisasi pengumpulan dan interpretasi data yang berpusatkan manusia. Secara khusus membahas struktur perancang bandar yang dapat digunakan sebagai kaedah empirikal semasa proses perancangan bandar. Kesimpulannya, penerapan kaedah yang disarankan yang dikenal pasti
\end{abstract}


dalam kajian ini membantu dalam keputusan reka bentuk untuk beralih ke arah kenyamanan iklim di ruang bandar.

Kata kunci: Perubahan iklim, Iklim bandar, Keselesaan iklim, Ruang bandar, Persekitaran pejalan kaki

(C) 2022 Penerbit UTM Press. All rights reserved

\subsection{INTRODUCTION}

According to the UNDP report (2019), ten cities had 10 million people in 1990. The number of mega-cities increased to 28 by 2014 and was projected to exceed 33 by 2018 . Moreover, 9 out of 10 future mega-cities will be found in developed countries. Keeping that in mind, the current greenhouse gaseous emissions are more than 50\% higher than the emissions in 1990. Global warming brings long-lasting changes to our climate environment, and the threats are irreversibly consequential [1]. Climate change has become a significant reality worldwide and in recent decades. During the last century, the global temperature has increased by at least $0.8^{\circ} \mathrm{C}$, while the atmospheric CO2 concentration has risen from $280 \mathrm{ppm}$ to $370 \mathrm{ppm}$. These values are expected to double by the year 2100 , with a concomitant temperature increase of between 1.1 to $5.4^{\circ} \mathrm{C}$ above the 1900 level [2].

The IPCC's most recent scientific assessment concludes that the Earth's climate changes in every area and across the whole climate system. Many of the alterations are unparalleled in thousands, if not millions, of years. Some, like ongoing sea-level rise, are unstoppable over hundreds to thousands of years. The impact of human effect on the climate system is indisputable, according to the paper. It also demonstrates that human activities can still influence the future path of climate, pointing to significant and long-term reductions in carbon dioxide and other greenhouse gas emissions as a means of limiting climate change [148].

Consequently, one of the most critical issues faced by society today is climate change. Nature and human consequences in towns are the first to be felt [3]. Accordingly, the cities are the drivers of transformative actions, especially in addressing the sectoral, demographical, spatial, and ecological challenges of climate change and extreme disaster risks [4]. In turn, the global decision-makers promote the idea of "resilience to climate changes" as a mix of co-benefits between mitigation, adaptation, and sustainable growth [5]. The cities are gaining political salience within the current global agreements, such as the Paris Agreement (2015) published by the United Nations Framework Convention on Climate Change (UNFCCC), followed by the Sustainable Development Goals (SDGs) and the New Urban Agenda (2016) of Habitat III [6,7]. All these global mechanisms noticed the centrality of local populations and policymakers in adapting to climate change. However, these mechanisms remain uncertain on implementing the cities' improvements inequitable, effective, and inclusive manners [8].

Urban development has also led to the Urban Heat Island phenomena (UHI) [9] that contributes to the metropolitan environments as the significant rise in air temperature and thus exacerbates the climate change impacts by rising heat waves [10, 11]. So, a willingness to "control" climate change effects, either from the emissions or from the adaptations perspectives, particularly when looking at the urban areas, is urgently needed [12]. In this context, as an interdisciplinary science, urban design should play an active role in balancing human needs and addressing the most critical climatic concerns, including climate change. Hence, the urban planners and designers must develop environmentally sustainable and climatesensitive urban designs, each with practical guidelines for policy-making and urban processes. This review aims to gather and synthesize current knowledge on the impacts of personal thermal exposure (with emphasis on thermal comfort) on the human body through a comprehensive and systematic literature review.

The success of urban space depends directly on the number of people who use that space. Promoting climate comfort can lead to the presence and prosperity of urban spaces and improve these spaces as urban places. Thermal comfort is a basic need in public space; without it, it is difficult to determine how other space needs can be met. The lack of codified and comprehensive principles in methods to improve thermal comfort in urban open spaces is exacerbated by the novelty of the issue and the significant delay in discussing thermal comfort quality concerning open urban spaces. Furthermore, the complexity of issues related to thermal comfort, which is related to climate as an unstable phenomenon on the one hand and humans on the other, has made it difficult for designers to use the methods available to them; as a result, it has stabilized the need to develop principles, methods, and tools that provide a place to meet the climatic needs of urban spaces through design. Thus, This review aims to compile and synthesize the current information on human-scale microclimate indicators (with emphasis on thermal comfort) through a thorough and systematic literature review. The systemic analysis follows the following steps: (1) the literature sample or universe was compiled by utilizing a set of stringent eligibility requirements, (2) the critical information regarding the state-of-the-art areas from each qualified source were obtained, derived and identified, 
and (3) the emerging issues in the literature sample were studied and analyzed to further distinguishing the opportunities and obstacles for the future studies.

\subsection{METHODOLOGY}

The universe of research was described as "the whole body of documentation to be generalized in this report," following a comprehensive analysis of literature relating to thermal comfort. This study narrowed the methodological measurements of thermal emissions in the built environments to personal exposure. The concept of thermal comfort was expanded to a state of mind that signifies satisfaction with the thermal environments [85].

The literature base analysis in this field contributed to the experiments beyond the reach and viability of this review. A set of eligibility requirements was then defined to resolve the research applications to this study. This is a vital step in the systemic evaluations to ensure that the debates are accurate and representative. Then, by dividing the article's content into two parts, decomposition and composition, an attempt has been made to explain each of these subsections to develop a decision-making framework used as a conclusion.

\subsection{Qualification Criteria}

A representative selection for analysis and assessment was performed based on the following multi-stage parameters (Figure 1). First of all, the evaluations were restricted to peer-viewed trials to reach a suitable sample size, where the thermal comfort indices were measured by sensing, simulating, or data processing. Secondly, the 'Microclimate Index' criterion was evaluated, and the micro-climate studies were described as local environments, sometimes with a slight variance but often with a significant differential within the vicinity. Finally, the priority was given to the urban and built environments, excluding the studies based on the data collected from repatriated weather stations situated farther from the urban areas or the studies with minimal significance to the urban and developed environments. In this sense, all the indoor dimensions, outdoor and intermediate spaces offered a holistic view of custom heat exposure.

\subsection{Classification Of Literature Sample}

There are various facets to the thermal comfort effects on human life, including physical and mental health and human comfort, reliability, and performance. As this thermal comfort has broad impacts, the new strategies and efforts to track personal heat exposures focused and span on various fields and the spinning sectors of environmental research and architecture, urban climates, construction infrastructure, public health, occupational health, and sports science. Consequently, to include an in-depth review of the state-of-the-art, the literature surveyed and included in this study were differentiated based on the targeted outcomes. Besides, the goals to track customized thermal exposure in any field differed significantly, such as reacting with traditional thermal exposure studies, determining the spatial and temporal error, and excluding psychological reactions.

\section{Literature Database}

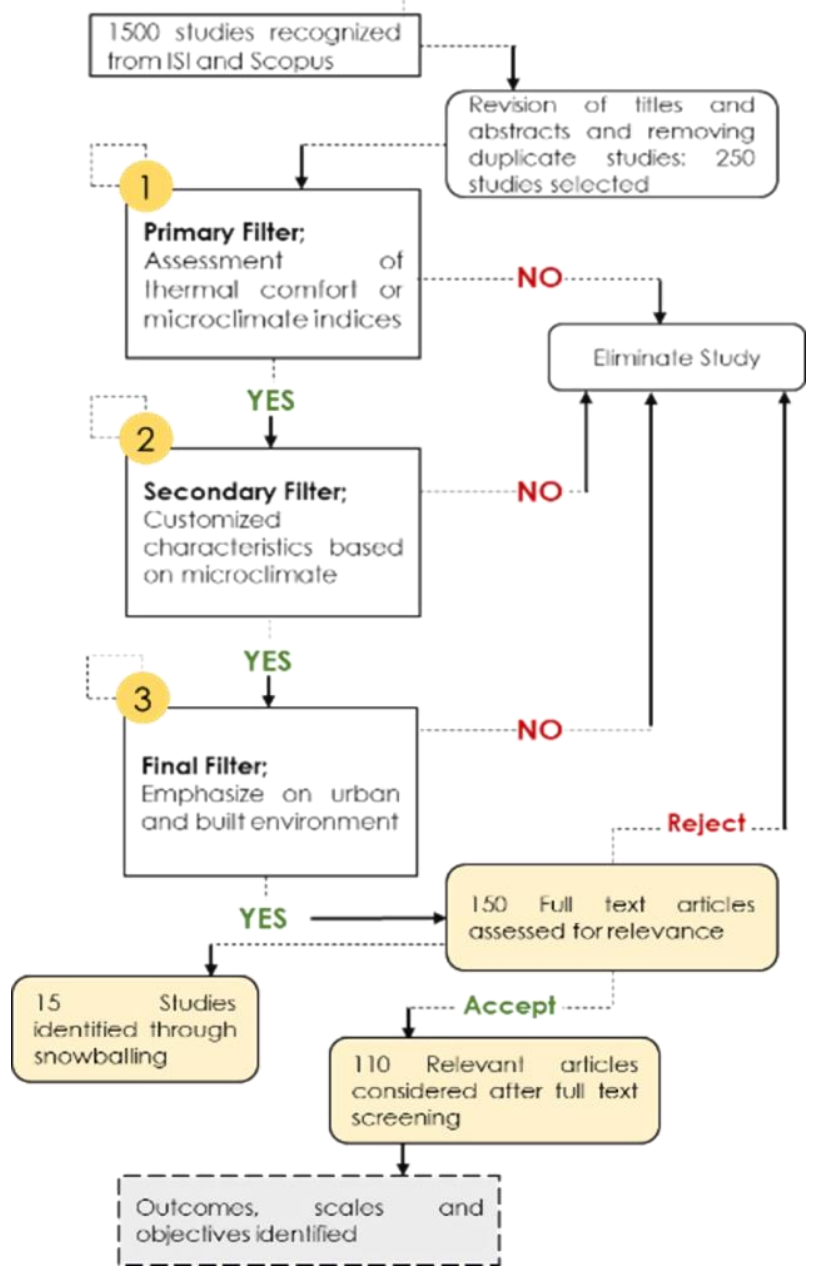

Figure 1 Flowchart demonstrating the selection of literature for evaluation and review

\subsection{DECOMPOSITION: DESCRIBING THE LITERATURE CONTENT}

\subsection{Urban Sustainability}

Sustainability is generally referring to the ability to preserve. Subsequently, the required change is an advancement that tackles the existing problems without addressing the potential demands. Hence, supportable improvements require three primary compromises: natural, social, and monetary maintainability. It gives a principle area to different maintainability guidelines [13]. The most significant 
parts involved in all daily actions, like innovations, decisions, policy measures, and business strategies, aim to improve the existing urban fabrics, economies, and (infra)structures. However, urban life's collective impacts are persistently unsustainable, and in contrast, are creating negative ecological impacts, social tensions, and economic crises [14]. Therefore, there is a need for more significant and more profound changes to the new societies, systems, and sustainable behaviors, rather than the less unsustainable approaches [15].

Sustainable developments must be equitable, livable, and viable. It is considered a drawback for sustainability to have a poorly established philosophical foundation [16], unrivaled development in the various dimensions of sustainability, particularly in the environmental aspects. Many of the authors claimed that the definitions of sustainability vary according to the target areas of researchers [17]. Turcu (2013) stated that there are no generally and widely agreed concepts of sustainability. Sustainable development means achieving enduring developments that address human needs and life quality improvement. Simultaneously, the urban areas should utilize natural resources at a level maintained by the ecosystem's regenerative potential [18]. According to Mori and Christodoulou (2012), the nested approach supported the hierarchical approach to biophysical, social, and economic sustainability. The study argued that the social, economic, and environmental aspects could not cooperate in the triple bottom line framework. The functioning life-support systems, social structures, institutions, and economies depend on each other. Even though this approach was explained as having limited scope, it is essential to mention that the nested hierarchy approach considers the Earth's biophysical limits as the final boundary containing social and economic parameters [19].

According to Pupphachai and Zuidema (2017), sustainable development provides a more general direction for evaluating and streamlining urban function and structure policies than a precise definition [20]. Consequently, the Sustainable Development Goals' development was created with 17 broad goals and 169 interconnected targets, based on the national priorities [21]. The Sustainable Development Goals (SDGs) and targets were clarified in 2015 [22] and provided the explicit goals of achieving a holistic solution to sustainable growth for both developing and developed countries for the next 15 years [23]. These goals are more integrated into the policy than the Millennium Development Goals (MDGs) because the nations can prioritize their targets and goals over national scales and local conditions while working with the internationally accepted norms. The SDGs are accompanied by accurate indicators and goals with a "means of implementation," including financial, trade, technological transfers [24].

At this point, the urban boundary concept is still lacking. As the urban areas extend beyond their political or administrative boundaries, the sustainability measurement in politically defined urban areas is irrelevant, arbitrary, and reduces the ground's reality. [25]. However, the importance of political and administrative boundaries persists and is not challenging since they have a clear route to provide sustainable societal policies [26]. Looking at the sustainability approaches from a policy perspective is an essential link in the sustainable development processes. This enables the examination of practical steps in realizing sustainability strategies as a handy tool. According to Tang and Lee (2016), the concept of sustainability at the management and decisionmaking levels consisted of three main parts, i.e., the policy-making, the decision-making, and the problemsolving processes (Figure 2) [27].

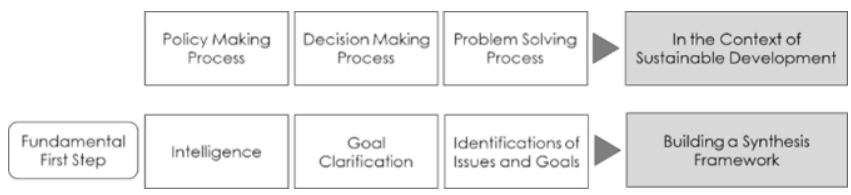

Figure 2 Building a synthesis framework as a fundamental first step [26]

Newman and Jennings (2012) defined sustainable urban ecosystems as the "ecosystems which are ethical, effective (healthy and equitable), zero-waste generating, self-regulating, resilient, self-renewing, flexible, psychologically-fulfilling and cooperative.". Hence, sustainable urban developments include:

1. improving the quality of life through social interaction and easier access to a wide range of services;

2. minimizing energy consumption via green buildings designing technologies;

3. sustainable transport;

4. environmental protection and restoration [28];

5. renewable energy and waste management;

6. green economies, including clean technologies, green tax policies, and green infrastructure [29];

7. environmental justice and equity through public health and welfare by natural resource management, including affordable housing, efficient transport, and community participation in policy decisions. [30].

8. Preserving the public spaces, as well as the cultural and natural heritages [31].

Urban sustainability includes the balance of biodiversity, energy, materials, and environmental issues like air pollution, heat island, and noise pollution. Peter et al. (1998) defined sustainable urban indicators as "physical, chemical, ecological or socio-economic measures" that calculate the environmental or complex ecosystem variables [28]. Although the indicators are measuring the sustainability progresses, their applications are not accessible across different cities or regions. The cities have different sustainability definitions, but the definitions are the indicators designed to measure sustainability for a particular city; thus, the definitions in one city may not apply to another city [32]. Apart from a spatially focused 
approach, no particular criteria for urban sustainability indicators distinguish them from sustainable development indicators [33].

Based on the revisions in earlier sections, sustainability consists of three general economy, society, and environment subsets. Each dynamic interaction of these three components can pave the way for sustainable urban developments. Meanwhile, the issues stated in the "Environmental Sustainability" are among the most critical challenges in recent decades and have always attracted designers' and urban managers' attention. Due to its productive forces, the field has a wide range of research within the sustainability concept. Hence, the "Environmental Sustainability" approach for further research was studied briefly in the rest of this research.

\subsubsection{Sustainability and Environment}

The World Commission for Environment and Development (WCED), established in 1987, produced a document entitled "Our Common Future (Brundtland Report)" coordinated by the Commission, Gro Harlem Brundtland. Briefly, the report stated that "Sustainable development addresses present-day needs without undermining future generations' capacity to fulfill their own needs" [34]. This report is historically significant for two reasons. First, it introduced the international discourse of authoritative imposition according to the principle of obligation for the future. Second, the possibility of challenging development ideas is a concept that has long been indisputable. Combining the word "growth" with the adjective "sustainable" has resulted in an exceedingly critical implication as it established the difficulty in maintaining the current and accurate definitions of exceptional development without any adjectives. [35]. Sustainable development has been an integral aspect of urban policy and planning. Environmental sustainability studies guide cities' planning or governing due to problems like population pressure and proximity to resource limitations, the current or anticipated exogenous environmental impacts, and a greater sense of global responsibility [36]. The ecological environment is critical for everyone because it can provide for human survival, materials basis development, and the necessary conditions. Moreover, human beings cannot survive and develop in an inappropriate ecological environment. In conclusion, human existence and developments are dependent on a suitable environment [37].

\section{Ecological Urbanism}

Ecological urbanism is a viable approach among the conventional approaches to achieve environmental sustainability and to establish a close interrelation between the city and nature. [38]. Ecological urban design is critical for the city's sustainability and offers a structure to address the ethical problems (including climate change and environmental equality), followed by human health, security, welfare, importance, and enjoyment needs. The principles are described but not exhaustive: 1) The cities are a part of the natural world, 2) The cities are habitats, 3) The cities are ecosystems, 4) The urban ecosystems are interconnected and dynamic, and 5) Each city has a profound and enduring structure [38].

\section{Nature-based Urbanism}

The potential for urban planning and political approaches introduction based on the ecosystems is becoming increasingly popular with both the scientists and policymakers, as these approaches offer sustainable and cost-efficient solutions for water management [39], air quality [40], and urban biodiversity [41], additionally for cross-cutting challenges like biodiversity conservation, public health, and wellbeing [42].

The scientists are being encouraged to switch from ecosystem-based to natural-based solutions (NBS) to collaborate with the communities on climate adaptation, mitigate climate change effects, conserve biodiversity, and improve the wellbeing of human health [43]. Natural resource conservation and environment support programs are critical to accomplishing the objectives of sustainable developments. NBS is directly relevant to several policy areas and interacts with several others through their systemic nature, such as land use and town planning [44].

Many researchers have drawn on the ecosystem services guidelines to evaluate the biophysical or financial impacts of ecosystem-based approaches in the cities [45] and examine the synergies potential and trade-offs between the ecosystem services bundles [46]. Although the Intergovernmental Platform on Biodiversity and Ecosystem Services (IPBES) draws on a more holistic definition of natural responsibility to the society, it also acknowledges that environmental decision-making needs to uphold various principles forms, particularly the ideals correlated with many world views regarding human interactions and knowledge-based structures [47]. The European Commission supports and incorporates these principles into the EU, a national accounting and monitoring structure that measures and assesses ecosystem resources and their economic impacts [48]. Furthermore, a realistic and detailed road map severely lacks the mechanisms that make the evaluation feasible and the appraisal of mutual gains in and through the implementation and decisionmaking phases [49].

A recent review of EU policies showed that the policy and planning begin on the concept of ecosystem services [50]. In some instances, an environmental assessment is limited to the specific problem areas (i.e., biodiversity and ecosystems), while the inter-sectoral effects (i.e., biodiversity-economical links) are rarely discussed. Moving forward, the solutions implementations include the toolkits for decision taking to simplify, systematize and evaluate the co-benefits in supporting decisions [48], the processes for reflecting, 
connecting, investigating, modeling, exploring, doing, and suggesting the solutions [51], and the supports of multidimensional communication networks for delivering co-benefits in the real-world contexts [52].

\section{Climate-sensitive Urbanism}

Urban areas are among the most susceptible regions to climate change impacts. Hence, the studies on cityclimate interactions are rising in numbers. The Climate Sensitive Urban Design (CSUD) principle acknowledged that urban architecture could be used to introduce changes to the urban landscape, enhance cultural, geographical, practical, and aesthetic advantages, and resolve climate change concerns in order to enhance urban resilience [53].

With a few exceptions, the urban planning systems worldwide have their origin in the Western town planning ideas that emerged during the end of the 19th and the beginning of the 20th century [54]. These planning ideas in Europe and North America are based on urban modernism and include rigid zoning regulations, wide streets aimed for motor vehicles, low plot coverage, and significant setbacks. These concepts were either "copied" from the West or were imposed by the foreign powers during the colonial period. Although the adjustments to local conditions have taken place after the colonial period, the principles have remained mainly the same [54]. Apart from that, the urban areas play significant roles in the climate change we are facing today. The UNEP/UNHABITAT (2005) reported that urban activities constitute over 80 percent of anthropogenic carbon dioxide emissions produced each year globally. Urban forms and design variables included the orientation, surface materials, urban texture, density land cover, ground surface evapotranspiration, building materials, building technologies, and shading effects provided by trees, directly influencing the microclimate cities. This medium proves that most urban areas' activities significantly contributed to the overall climate change [55].

A primary reason to study the urban climate effects is to apply the knowledge acquired to plan new climatically sensitive settlements or address climatic problems in the existing settlements [56]. Besides, the design awareness that follows the environment and climate needs is increasing. In addition, different climatic aspects such as the climate circumstances, seasonal variations, and climate change bring additional urban development planning and design needs. So, the urban' climate-sensitive design includes the processes that consider the significant indices of microclimates (e.g., sun, wind, temperature) for design purposes. This concept is applied to benefit from the existing urban microclimates, mitigate the stressed conditions, and decrease the adverse effects through design and planning options [57].

The planning and design practices incorporated into the overarching governance systems can be categorized into the global, region-national, city, neighborhood, and plot/building practices scales (as shown in Figure 3). The actors in these systems include the governments, private and public land developers, public representatives, professional planners, designers, and citizens, as shown in Figure 3 as examples. In essence, on a global scale, the climate context is established by various international agreements, such as the United Nations Framework Convention on Climate Change (UNFCCC). These agreements required the ratifying parties to limit emissions of greenhouse gases (GHG) at regional and national scales. Furthermore, equivalent policies stipulate legally binding air quality standards at city-scale policies or manage extreme events like heatwaves and floods enacted at the neighborhood scale. Therefore, the amount and character of green space and its distribution that can affect local climate are made on different scales. Finally, the choices on landscaping, building insulation, and so on to manage the microscale climate and building energy usage are made at the plot/building owners and occupiers [56].

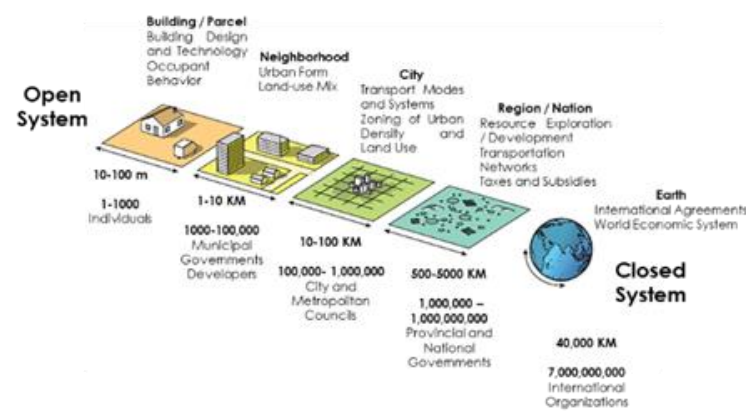

Figure 3 The hierarchies of scales at which actors (whether individuals or organizations) make decisions affecting changes in urbanized landscapes [56]

While the cities play crucial roles as the generators of economic wealth, their role in enabling their populations' wellbeing is of equal or greater importance. In the context of climate change, various direct and indirect impacts threaten both of these roles. The direct effect of climate change takes the binary form of shocks and sudden impacts, such as storms, typhoons, heatwaves, and stresses, that build gradually over time with sea-level and overall temperature shifts in precipitation trends (Figure 4). In turn, such events generate an outpouring of indirect impacts that will erode the city's capacity to adapt due to the significant socio-technical system disturbances [58].

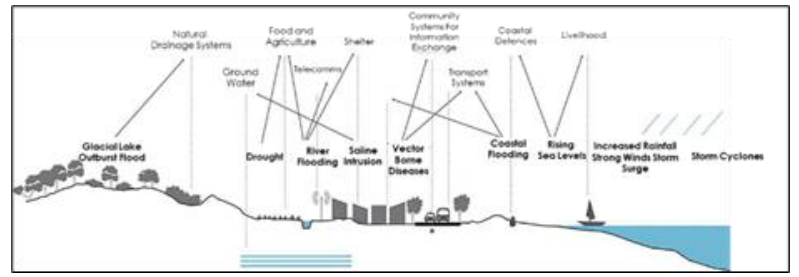

Figure 4 Climate change impacts could affect several essential urban functions via direct and indirect effects [58] 
These effects are especially felt by the vulnerable communities suffering from widespread deprivations because of their heightened sensitivity to the threats or their limited ability to adapt due to low assets levels [59]. Figure 8 shows the compound effects of climate change, in addition to the direct impacts, indirect impacts, and pre-existing vulnerabilities. The definition of climate change adaptation applies to the interventions aimed at minimizing the natural and human systems' vulnerability to the actual or anticipated climate change effects [60]. Figure 5 explains that the actions to improve the vulnerable urban populations' adaptive capacity must focus on disaster risk reduction (DRR) and decreases urban poverty, but these activities are currently insufficient. It also needs concrete measures to improve the city's capacity to preserve the vital positions that foster its people's wellbeing and sustains its economy. Such initiatives must understand the consequences of climate change in the sense of how the city (the metropolitan system) operates and which are less able to address shocks and stresses [61].

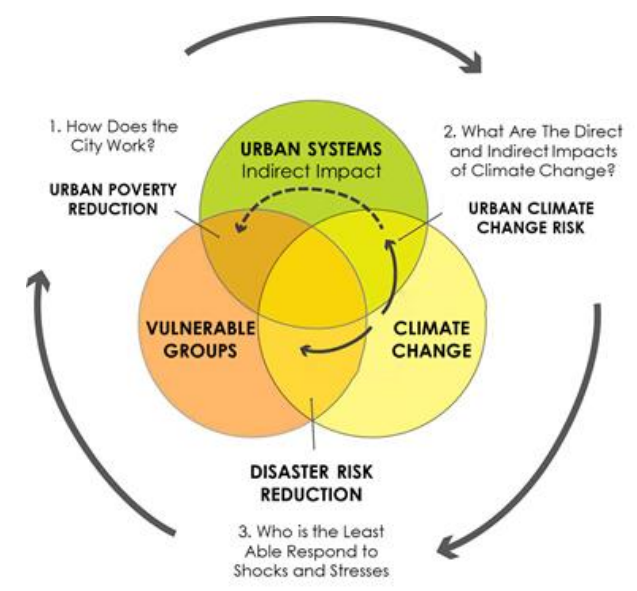

Figure 5 Climate impacts: a compound effect combines direct, indirect, and pre-existing vulnerabilities [58]

\subsection{Urban Climatology}

Although human beings have adapted to their environments throughout history, climate change still poses new and unique challenges threatening their lives and livelihoods. In the past two decades, attention to climate change adaptation has increased due to the increasing risks and the growing uncertainty of climate change. The climate change term came into action in the 1990s and had gained momentum partly due to the Intergovernmental Panel on Climate Change (IPCC) definition. This definition was most recently in its fourth assessment, was stated as "adjustment in natural or human systems in response towards actual or expected climatic stimuli or their consequences, which moderates damage or takes advantage of benefits [2]. Besides, several of the United Nations Framework Convention on Climate Change's (UNFCCC) Conferences of the Parties (COP) discussed this growing body of practices. The presentations culminated to form the COP 21 and highlighted the emerging need to establish a global aim to adapt to "enhancing adaptive capacity, strengthening resilience and reducing vulnerability to climate change" [6].

In addition to global challenges, urban areas have unique climate risks. For example, urban heat islands, impervious surfaces exacerbate flooding, and sea-level rise threatens coastal development [61, 62, 63]. Also, the urban areas housed most of the world's populations and acted as the global economic hubs, thus exposing many assets to climate change hazards [59]. The urban areas also present unique adaptation opportunities. First, the adaptation decisions often require localityspecific actions and are best tailored by the local-level decision-makings [5]. Second, the urban areas are also the contexts to innovations; hence, they may efficiently garner and use resources. Many charitable foundations are eager to fund local adaptations and spanning avenues, such as the Kresge Foundation's Urban Adaptation Assessment to analyze the urban areas regarding their vulnerability to the changing climate and the readiness to adapt. The project will help elevate the critical climate action needs, informing infrastructure, land use, water resources management, and transportation. This is followed by other policies and funding issues to motivate the communities to act and be informed about the methods to make them stronger and more resilient to climate change. Fourth, the cities' importance in adapting to climate change has led to a recent surge of interest and "oneupmanship" between the cities, as demonstrated through the growing interest of populations as recorded in C40, 100 Resilient Cities [64]. As a result, many cities are developing their adaptation efforts and increasing urban adaptation studies [65]. Besides, the Georgetown Climate Center's Adaptation Clearinghouse tracks some state-level adaptation plans, and the studies have examined the contents therein [66]. The emerging academic literature discovers the need for progress in urban adaptation [67]. Policymakers have gone through significant adaptation evaluation work on the country level, including tracking their vulnerability, adapting to climate hazards, and national progress in their adaptation planning [68].

\subsubsection{Urban Ecology}

Urban ecology is the study of the structures and functions of human-made environments, followed by how the living and nonliving parts of those environments relate to each other and the energy flow, materials, and nutrient quantification required to sustain the urban systems. Urban ecological studies can be conducted in many ways and at multiple scales. There is generally a distinction between the cities' ecology and the ecology in cities [69]. Urban ecology contains two closely related perspectives [70, 71]. The first addresses the ecology in urban areas and is closely allied to traditional ecology by investigating the 
ecological patterns and processes in urban areas and other environments. The second one indicates much more significant socio-economical components by acknowledging the human activities' dominance in shaping the urban ecosystems [72].

\subsubsection{Urban Ecosystems}

The urban ecosystem refers to the relationships between the living organisms, communities, and abiotic environment in cities [74]. The inextricable relations between the human and abiotic components in an environment are a fundamental concept for ecology. The biological community of species (for example, vegetation, plants, and people) and the abiotic environmental habitats are combined to form the urban ecosystems (Figure 6) [56].

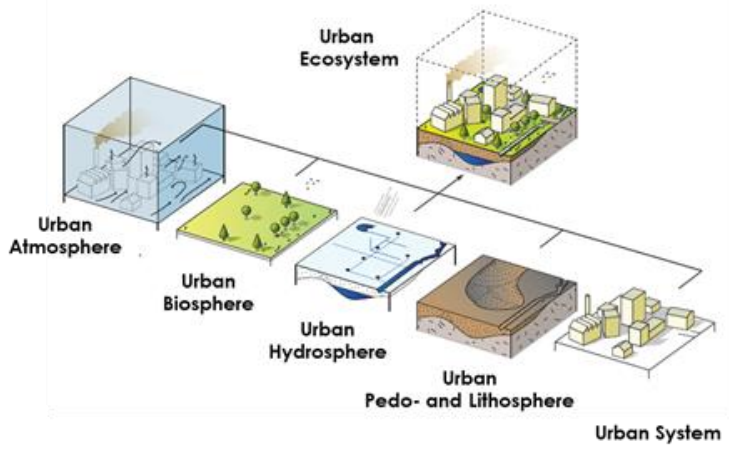

Figure 6 The biophysical components that comprise an urban ecosystem [56]

From another perspective, Alan R. Berkowitz et al. (2002) defined an urban ecosystem as the model based on the relationships between the social, biological, and physical components (Figure 7). It is possible to recognize this relationship by understanding that urban environments are complex and are affected by increasing driving forces [74].

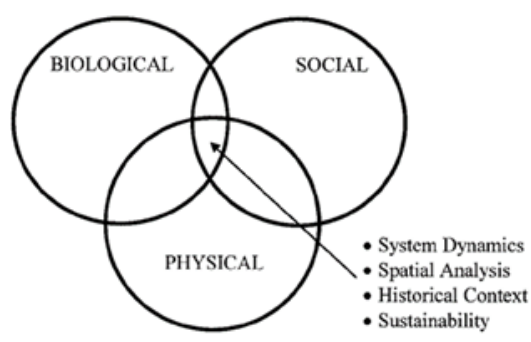

Figure 7 A simplified model for understanding urban ecosystems as the interaction of a city's social, biological, and physical components. [74]

\subsubsection{Urban Metabolism}

The critical functions of an ecosystem cooperate with metabolism. Metabolism is explained as "the chemical and physical processes which a living thing uses food for energy and growth" (https://dictionary.cambridge.org/us/dictionary/english / metabolism), or as "the sum of the physical and chemical processes in an organism by which its material substance is produced, maintained, and destroyed, and by which energy is made available," and as "any basic process of organic functioning or operating; changes in the country's economic metabolism,"

(HTTPS:// www.dictionary.com/browse/metabolism). Therefore, metabolism refers to both biological/physiological processes and social processes [73].

The city is an integrated open system consisting of living things interacting with their physical environment. This system is 'open' to the import and export of both energy and mass. In detail, it means that the city's builtup area cannot exist without support from the outside boundaries of the system. In analog to a living organism metabolism of 'transforms substances into tissue with an attendant release of energy and waste,' the urban metabolism is described as the flow and transformation of materials and energy in a city (Figure 8) [56]

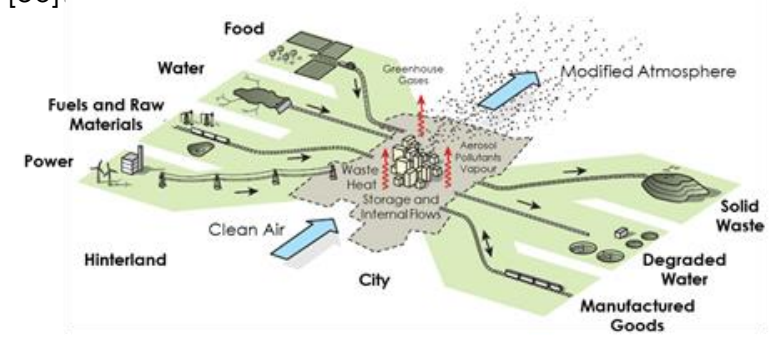

Figure 8 Represents inputs to, and outputs from, an urban ecosystem (Modified after Christen 2014; (c) Elsevier, used with permission) [56]

Applied urban climatology involves planning to achieve local climate conditions ideal for humans in the urban canopy layer. The German Meteorological Society's biometeorology experts have defined the expression of 'ideal urban climate' as follows [75]: "Ideal urban climate' is a spatially and temporally variable state of the atmosphere within urban structures containing as little air pollutants produced anthropogenesis as possible. Besides, urban planners and designers should offer a tremendous spatial variety of urban microclimates to the urban population (characteristic length of urban spaces with different climates related to cities in mid-latitudes: about $150 \mathrm{~m}$ ) by avoidance of extreme conditions " [75].

The awareness of urban climatology increased in the past decade. Urban climatology is affected by a town or city and is conducted to raise the conditions in cities; hence the dramatic thermal shifts are discovered and experienced. Urban climatology research mainly involves experimentation, observation, and numerical weather modeling and focuses on urban-related weather phenomena. Such occurrences are the urban heat island (UHI) environmental concerns, as characterized by the warmer cities, compared to the 
surrounding environment. The mitigation and understanding of UHIs have been targeted by urban meteorologists and climatologists for many decades [9].

\subsection{Urban Climate Indices}

The interactions between the urban climate and energy demands, outdoor comfort, and energy systems are intricate and interconnected. However, the urban microclimates' modeling is very complicated because of the cities' geometric complexity, heterogeneity, and atmospheric phenomena [12]. The cities and the climates are two human-made and natural systems that have a close relationship. The different city spaces, such as buildings, green spaces, urban networks, are designed by paying attention to the functional, visual, and aesthetic qualities, besides the need for attention to the city's climates and by observing the climatic design criteria. The climatic determinants in the design structures of urban spaces include four main elements, e.g., "Solar Radiation," "Wind Flow," "Relative Humidity," and "Temperature." Managing the two indicators of solar radiation and wind flow makes it possible to control the relative temperature and humidity to the desired level. Therefore, the first step in climatic design is to be sufficiently aware of the impacts of the changes in these climatic elements on the process of environmental comfort.

\subsubsection{Solar Radiation}

The energy that causes what we call the climate begins with the sun. The sun's energy comes to the Earth in electromagnetic radiation form. All the objects give off electromagnetic radiations as waves with peak-to-peak lengths that depend on the objects' surface temperature. The sun's surface temperature is near to $6000^{\circ} \mathrm{K}$, and the electromagnetic energy from the sun that can penetrate through the Earth's atmosphere has a peak in the 400 to 700-nanometer range, which is visible to humans $(\mathrm{nm})$. The total range of the solar spectrum on Earth is from approximately $280 \mathrm{~nm}$ to $3000 \mathrm{~nm}$ (or 0.28 micrometers, abbreviated $\mu \mathrm{m}$, to $3 \mu \mathrm{m})$, and this whole short wave range is known as solar radiation [73]. Hence, the cities are the first field with solutions closely connected to energy consumption that can be tackled and ultimately solved. Solar urban planning is a current topic that stemmed from the inadequacy of traditional urban planning processes regarding solar capacity. So this issue is a determining factor to reach smart energy cities formed by zero energy buildings. Le Corbusier's vision for the modern city was not carried out. Still, his vision constituted an innovative impulse to consider urban planning the first field to apply solar designing logic [76].

Urban planners and energy researchers have always considered solar radiation and its related issues as the active components in the urban development processes. Among the many solar energy cases, this paper covered the Urban Heat Islands (UHI) and "Outdoor Thermal Comfort" as the two productive urban design areas. The two areas are discussed in depth in the following sections.

\section{Urban Heat Island}

Today, the most critical problem in urban areas is increased surface temperature due to improper urban design. With the importance of the urban thermal island, many studies have been conducted to identify the factors affecting its increase and decrease. The micro-climate and air quality in urban spaces are of great benefit to the wellbeing of citizens. Control of urban heat islands is one of the most important concerns for improving human comfort and health, especially in hot climates. It is relatively easier to achieve thermal comfort inside the building, while it is much more challenging to achieve this comfort in open spaces, and therefore much less work has been done on it. The formation of urban thermal islands has become one of the severe challenges of the present age and has occupied the scientific community's minds. Attention to this issue in scientific articles and research has grown significantly, especially in the last decade. According to researchers, if rising temperatures continue, it will cause serious environmental problems and impose high costs on cities.

The term "heat island" describes a micro-climatic phenomenon that occurs in urban environments. It consists of a relevant air temperature increase within the urban areas and is generally warmer than the surrounding rural neighborhoods (Figure 9). The UHI phenomenon occurs in the winter and summer seasonal levels; thus, this issue is more severe for the population living in urban environments [77].

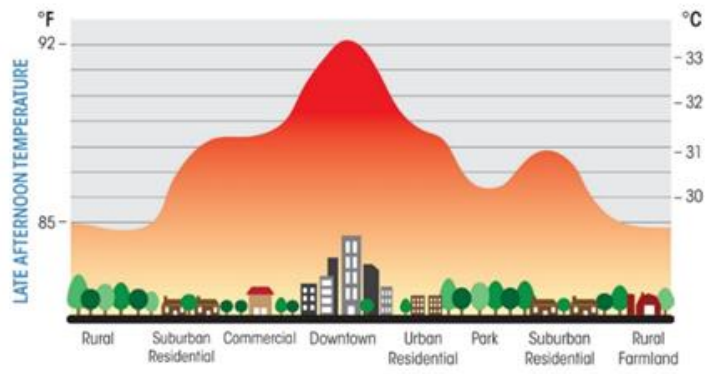

Figure 9 Urban Heat Island diagram (https://ecointelligent.com/2017/04/13/the-heat-island-effect/)

The increasing urbanization rate exacerbates the adverse consequences of climate change, as energy consumption increased by $14 \%$ during the last decade, primarily due to rapid urbanization. The researchers estimate that until 2030, at least 61 percent of the world's population will be living in the cities. Accordingly, the cities are projected to absorb ninetyfive percent of all the population growths in developing countries, almost four billion people [78].

Urban climates are a prime example of accidental climate modification that shows the unintended 
impacts of human activities on the atmosphere. The cities contribute to the changes in climate and atmospheric compositions at local, regional, and even global scales. In turn, the atmosphere impacts the cities' infrastructure, health, and safety, as the populations struggle to cope with extreme events such as storms, floods, and droughts. Proper understanding, description, and modeling of these interactions is needed to intelligently minimize unwanted and maximize beneficial aspects [56].

\section{Outdoor Thermal Comfort}

There are several reasons for creating comfortable outdoor environments in the cities. The importance of making urban space attractive and accessible has increased in recent years due to the social, cultural, and economic benefits. The use of urban space is more likely to increase if the outdoor environment is thermally comfortable, as it is also essential for the wellbeing of people. This concept is fundamental in warm countries, as the risk of heat-related illness increases with the higher temperatures. Furthermore, for most of the year, outdoor activities are possible in warm countries with the appropriate outdoor spaces' design that increases outdoor livability [79].

The collective effect of studying the environmental variables (i.e., air temperature, relative humidity, wind speed, and radiant temperature) and two personal factors (i.e., clothing insulation and metabolic activity level) is calculated and expressed in a thermal comfort index. The researchers worldwide used over one hundred thermal comfort indices to assess and predict the thermal environment's comfort levels, but most of these were designed to assess indoor conditions [80].

The other leading three thermal comfort indices, namely Physiological Equivalent Temperature (PET) [81], Universal Thermal Climate Index (UTCI) [79], and Outdoor Standard Effective Temperature (OUT_SET) [82], are specifically designed for outdoor conditions and outdoor thermal comfort studies. Besides the PET, UTCl, and OUT_SET indexes, the other standard outdoor thermal comfort indices include the apparent temperature (AT), adjusted apparent temperature (aAT), thermal discomfort index (TDI), Effective Temperature (ET), Operative Temperature (TOP), and Perceived Temperature (PT). Some of the studies also used the predicted mean vote (PMV) or adaptive predicted mean vote (aPMV), but the PMV steadystate assumption may be unreliable for the fluctuating outdoor conditions [83]. In an early study, de Freitas [84], in their case study, used the Skin Temperature Energy Balance Index (STEBIDEX) and Heat Budget Index (HEBIDEX) to define the thermal sensation threshold levels of beachgoers in Caloundra. Then, Pickup and de Dear [85] extended the Effective Standard Temperature (SET) thermal comfort index to apply it in outdoor settings. This thermal index holds two-node models [84] and has been used in various comfort research [86]. The recent studies on similar topics mostly used the PET or UTCl outdoor thermal comfort indices. A comprehensive review of thermal comfort indices had been thoroughly discussed by de Freitas and Grigorieva [87] and Coccolo et al. [88]. The ISO 10551 adopted the definitions of thermal preference, thermal sensation, and thermal acceptability from the ISO 10551 [89]. The American Society of Heating, Refrigerating, and Air-Conditioning Engineers (ASHRAE) defined comfort as "the condition of the mind in which satisfaction comes with the thermal environment" [90]. Two main approaches, energy-balance and adaptive approaches [91] have ben established to measure thermal comfort. The "Energy-Balance Approach" focuses on the heat loss from the body being equivalent to the heat produced, while the "Adaptive Approach" focuses on the perceptions of comfort, including the elements like psychological factors, cultural background, and preferences [92].

\section{- $\quad$ ENERGY BALANCE APPROACH}

Climate conditions in urban regions differ from rural areas, with greater temperatures, less diurnal temperature fluctuation, changes in wind direction and speed, altered heat transmission, and an outstanding rainfall balance. This phenomenon, known as the urban microclimate, has a variety of significant consequences on city sustainability [142].

- Environmental Effects: In hot climates, especially in the summer, the increase in temperature implies an increase in the need for cooling energy. Numerous studies have found a link between rising city center temperatures and $\mathrm{CO} 2$ emissions and photo-oxidant gas concentrations [143], [144], [145].

- Economic Effects: Building air-conditioning loads (residential and commercial) results in significant energy consumption and a rise in process costs and higher expenses for more powerful mechanical equipment. Furthermore, the added cost of delivering peak demand energy, as well as the hygienic expenses of air pollution and temperature rise, must be included [143], [144].

Social Effects: rising temperatures in densely populated regions may be a significant danger factor for health and mortality. Different studies have found that urban populations are more sensitive to heat impacts than rural, particularly vulnerable groups (children and the elderly). Increased urban pollution causes a variety of ailments, including cardiovascular disease, asthma, and other respiratory issues, among others. Furthermore, because outdoor areas are essential for pleasure and socializing, adverse microclimate conditions may impact their use [146].

The integration of microclimate factors into urban planning poses several challenges. The research into thermal comfort is extensive, so it is challenging to separate the physiological and psychological factors affecting subjective comfort experiences [93, 94]. The energy balance approach focuses on physiological factors. However, many comfort indices play critical roles in correlating the surrounding environments with thermal experiences. Ebrahimabadi et al. (2015) suggested that the quantitative thermal comfort 
estimation has "limited practicality" in cold climate planning because the cold climates are causing physiologically uncomfortable conditions most of the year due to low sun angles and low temperatures. Instead, the study suggested focusing on the climate parameters modified by design and significantly influencing thermal comfort [95].

\section{- $\quad$ ADAPTIVE APPROACH}

The adaptive approach is essential to be explored from a physiological perspective. Thermal comfort is almost impossible to achieve in outdoor places, especially in the winter months. The adaptation in the context of thermal comfort can be broadly defined as to "involve all the procedures through which people improve the fit between specifications of the environment"[94]. Nikolopoulou \& Steemers (2003) explored the adaptive approach based on the public spaces of Cambridge. The findings observed that the microclimatic parameters strongly influenced the thermal sensations and accounted for $50 \%$ of the variation between objective and subjective comfort evaluations. Psychological adaptions seemed to become increasingly important to explain the comfort level variations observed [94].

\section{Thermal Comfort and Micro-Climate Variables}

When designing with the climate, micro, or macroclimate of a particular geographical location, the process should consider the relationship between the climate, site, and occupants and the region itself to have a context-based microclimate condition. This follows the notion that human thermal comfort in urban design is achieved by understating the basic principles of bioclimatic design, which deals with maintaining thermal comfort within the region. As a result, thermal comfort is attained when a heat balance between humans and their surroundings. Designing, a climateresponsive building, require proficiency in the aspect of the climatic analysis of the area under consideration as a whole, thereby pronviding design strategies which favor the use of renewable energy, practical site analysis, proper choice of building materials, construction techniques, building forms, orientations, as well as effective use of vegetation. However, these design strategies depend on the microclimate of an area; that is to say, bioclimatic design happens to be a design concept that helps conserve resources while facilitating the use of the local climate surrounding an urban area [174].

As discussed previously, one environmental comfort subsets is thermal comfort based on the climatic conditions, but this is considered an important and complex discussion. The climate is accepted as playing a central role in defining the activities and in allocating outdoor use. So, most importantly, the environmental factors affect the degree of comfort, one of the leading climate change planning goals. The comfort levels can be measured and require the indicators to compare with the overall climatic conditions on the pedestrian scale. A single climate feature does not reflect the environment's thermal comfort conditions, such as a body with respective receptors to understand the ambient temperature. All the climatic variables considered a person to be a sense of environmental conditions. Therefore, to measure thermal comfort, it is necessary to determine the thermal characteristics. Table 1 represents the recent researches on the valid microclimate conditions, focusing on the thermal comfort of pedestrian scale users in urban spaces.

Table 1 Investigation of micro-climate variables affecting thermal comfort

\begin{tabular}{|c|c|c|}
\hline & & Parameters \\
\hline \multirow{8}{*}{1} & \multirow{8}{*}{$\begin{array}{l}\text { Microclimatic } \\
\text { Conditions of an } \\
\text { Urban Square: Role } \\
\text { of Built Environment } \\
\text { and Geometry [96]. }\end{array}$} & Relative Humidity \\
\hline & & $\begin{array}{l}\text { Monthly Average } \\
\text { Temperature }\end{array}$ \\
\hline & & Highest Recorded Air \\
\hline & & Temperature \\
\hline & & Wind Speed \\
\hline & & Solar Radiation \\
\hline & & $\begin{array}{l}\text { Mean Radiant } \\
\text { Temperature }\end{array}$ \\
\hline & & $\begin{array}{l}\text { Physiologically } \\
\text { Equivalent Temperature }\end{array}$ \\
\hline \multirow{4}{*}{2} & \multirow{4}{*}{$\begin{array}{l}\text { A field study of } \\
\text { urban } \\
\text { microclimates in } \\
\text { London [97]. }\end{array}$} & Air Temperature \\
\hline & & $\begin{array}{l}\text { Wind Speed and } \\
\text { Direction }\end{array}$ \\
\hline & & Air Humidity \\
\hline & & Global Solar Radiation \\
\hline \multirow{7}{*}{3} & \multirow{7}{*}{$\begin{array}{lr}\text { Role of } & \text { Street-Level } \\
\text { Outdoor } & \text { Thermal } \\
\text { Comfort } & \text { in } \\
\text { Minimizing Urban } \\
\text { Heat Island Effect by } \\
\text { Using } \\
\text { Program, Enviation } \\
\text { Case of Amman, } \\
\text { Jordan [98]. }\end{array}$} & Mean Air Temperature \\
\hline & & Evaporation \\
\hline & & Pollution \\
\hline & & Cloudiness \\
\hline & & Solar Radiation \\
\hline & & Mean Wind Speed \\
\hline & & Turbulence \\
\hline \multirow{3}{*}{4} & \multirow{3}{*}{$\begin{array}{l}\text { Urban growth and } \\
\text { pedestrian thermal } \\
\text { comfort [99]. }\end{array}$} & $\begin{array}{l}\text { Daytime (9 am-6 pm) } \\
\text { Distribution of PMV }\end{array}$ \\
\hline & & Surface Temperature \\
\hline & & $\begin{array}{l}\text { Mean Radiant } \\
\text { Temperature }\end{array}$ \\
\hline \multirow{8}{*}{5} & \multirow{6}{*}{$\begin{array}{l}\text { Potential } \\
\text { Contribution of } \\
\text { Urban } \\
\text { Developments to } \\
\text { Outdoor Thermal } \\
\text { Comfort Conditions: } \\
\text { The Influence of } \\
\text { Urban Geometry }\end{array}$} & \multirow{8}{*}{$\begin{array}{l}\text { Physiological Equivalent } \\
\text { Temperature }\end{array}$} \\
\hline & & \\
\hline & & \\
\hline & & \\
\hline & & \\
\hline & & \\
\hline & \multirow{2}{*}{$\begin{array}{l}\text { and Form in } \\
\text { Worcester, } \\
\text { Massachusetts, USA } \\
{[100] \text {. }}\end{array}$} & \\
\hline & & \\
\hline \multirow{5}{*}{6} & \multirow{5}{*}{$\begin{array}{l}\text { Parametric } \\
\text { Environmental } \\
\text { Climate Adaptive } \\
\text { Design: The Role of } \\
\text { Data Design to } \\
\text { Control Urban }\end{array}$} & $\begin{array}{l}\text { Environmental Comfort } \\
\text { Indexes }\end{array}$ \\
\hline & & Mean Radiant \\
\hline & & Temperature \\
\hline & & Predicted Mean Vote \\
\hline & & Physiologically \\
\hline
\end{tabular}




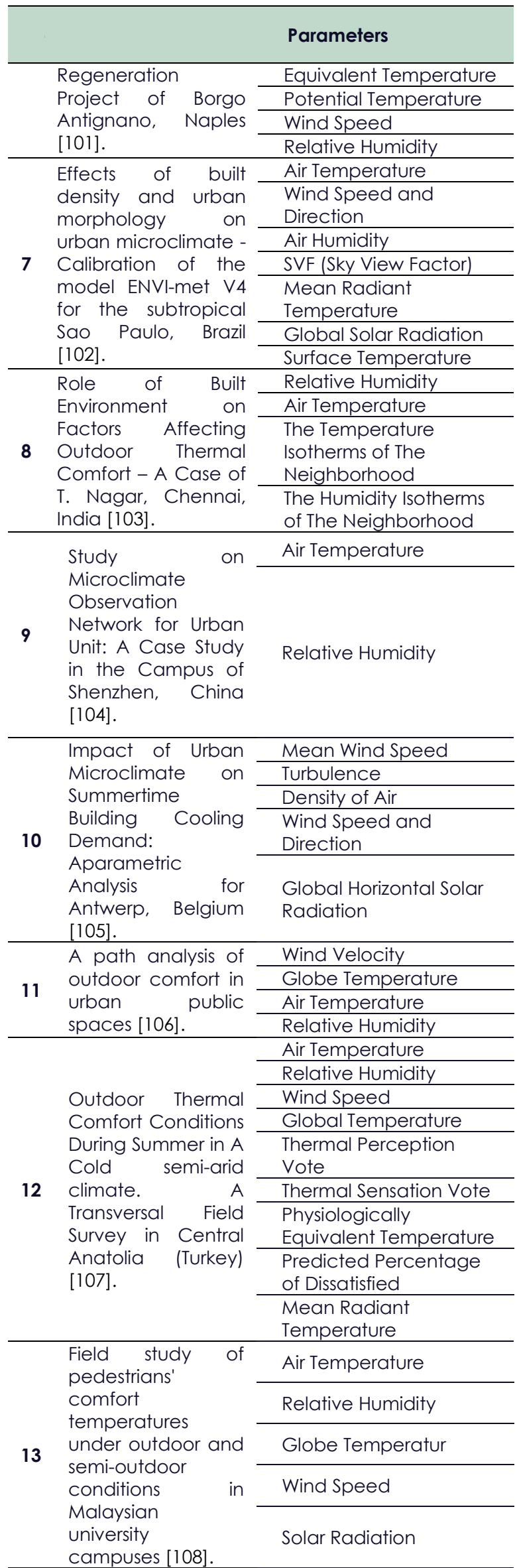

\begin{tabular}{|c|c|c|}
\hline & & Parameters \\
\hline \multirow{8}{*}{14} & Assessment & \multirow{5}{*}{$\begin{array}{l}\text { Outdoor Air } \\
\text { Temperature }\end{array}$} \\
\hline & Outdoor & \\
\hline & Temperature with & \\
\hline & Different Shaded & \\
\hline & Area within an & \\
\hline & Urban University & \multirow{3}{*}{$\begin{array}{l}\text { Average Air } \\
\text { Temperature }\end{array}$} \\
\hline & Campus in Hot- & \\
\hline & $\begin{array}{l}\text { Humid Climate } \\
\text { [109]. }\end{array}$ & \\
\hline \multirow{5}{*}{15} & Effects of Urban & Outdoor Air \\
\hline & Morphology on & Temperature \\
\hline & Microclimate & \multirow{3}{*}{ Relative Humidity } \\
\hline & Parameters in an & \\
\hline & $\begin{array}{l}\text { Urban University } \\
\text { Campus }\left[\begin{array}{ll}1 & 10\end{array}\right]\end{array}$ & \\
\hline
\end{tabular}

\subsubsection{Windflow}

The comforts assessment of pedestrians in urban spaces is crucial to confirm the local pedestrian usage population [111], as there are increasing concerns regarding the outdoor comforts of this population [94]. The local wind speeds and solar radiation are the microclimatic parameters primarily dependent on urban planning (such as the site position, building shapes, geometry, and the alignment of open spaces). Thus, the designers can work on the interactions between these climatic parameters and the urban morphologies to promote the pedestrians' comforts in public spaces [112].

\subsubsection{Relative Humidity}

The relative humidity $(\mathrm{RH})$ can be defined as the ratio between the actual amount of water vapor in the air and the maximum water vapor volume that the air can retain at that air temperature. Accordingly, the relative humidity of between $40 \%$ to $70 \%$ does not significantly and negatively impact the thermal comfort of humans [113]. The appropriate relative humidity results can be assessed by referencing the comfort zone reported in Givoni's Psychrometric chart [114].

\subsubsection{Air Temperature}

The air temperature refers to the temperature of the air surrounding the body. It is the most critical environmental factor that can be measured by the dry-bulb temperature (DBT), given in degrees Celsius $\left({ }^{\circ} \mathrm{C}\right)$ [113]. The appropriate air temperature can be assessed by referring to the comfort zone reported in Givoni's Psychrometric chart [114].

\subsection{COMPOSITION: RESULTS AND DISCUSSIONS}

The United Nations Framework Convention located in Paris hosted the Climate Change Conference of the Parties (COP21) in December 2015 and recognized the 
cities as the key actors in mitigation and adaptation, followed by the low emissions development and resilience inclusion. The COP21 Paris Agreement that had entered into force in November 2016 highlighted the significant roles of cities in implementing national commitments: "Agreeing to uphold and promote regional and international cooperation to encourage all Parties and non-Party stakeholders to pursue greater and more ambitious climate action, including ... cities ..." [6].

The cities can be the primary implementers of climate resiliency, adaptation, and mitigation. The Second Urban Climate Change Research Network (UCCRN) Assessment Report on Climate Change and Cities (ARC3.2) addressed the circumstances needed to realize these advantages. However, the cities could not address the challenges and fulfill their climate change leadership potentials without necessary transformations [115]. From another perspective, the buildings are responsible for around $40 \%$ or more of most countries' GHG emissions that contribute to climate change. The strategies for reducing their energy demands are an integral component of urban design. However, the cities need to offer their residents healthy and attractive indoor and outdoor spaces. A pleasant microclimate is critical but is often undermined by the current urban planning and seldom attempted to tackle climate change.

Furthermore, the building's operations and outdoor environments are thermodynamically looped [116]. When faced with climatic concerns, the cities are both problems and solutions. Therefore, we need to reverse our development trends, restructure frameworks, reform policies, and readjust our stakeholders. While the cities can remain the fat cats' sanctuary, they still need to accommodate the majority. Any simple change or transformation may take several years, if not decades. In conclusion, the cities are generally vulnerable, and yet the transformations are essential [117].

According to the previous arguments, the awareness of climatological inputs' importance in urban planning has grown in recent years. This is conceptual, knowledge-based, and related to technical matters, policy issues, organizational aspects, and the markets [118]. In addition to the previous discussions, the connections between good, sustainable city planning, and urban climate concerns are sharp and clear. Thus, good planning practices are, by their nature, are also climate-smart planning practices. The planners are directly involved in shaping and controlling physical land use and development patterns (urban form). The critical areas where the planners can support and lead adaptation and mitigation activities in their traditional planning capacities include the following [119]:

\subsection{Land Use Planning}

Careful attention to the physical land usage and urban form is how planners manage and adapt to climate change. For example, the planners are involved in the designation of land uses, can help in shaping the settlement patterns to reduce and to minimize the exposures to lands that are climatically hazardous (e.g., steep and unstable slopes, flood zones, coastal areas subject to sea-level rise and storm surges) [119]. The developments of land-use planning across the governance scales often have a good deal of local control. The leverage to use land-use planning to mitigate carbon emissions and employ the best practices to reduce transport-related emissions depends on the officials across different governance scales. This medium includes creating integrated public transportation systems, accessing multimodal transportation options, and co-locating housing and job areas to reduce commutes [120]. In this context, spatial planning, especially land use planning, is emerging as a policy that can influence adaptation and climate change mitigation [121]. The ways urban planners design cities to avoid risks can be evaluated through spatial planning, and the uncertainty and the complexities of climate change can be tackled. It is also a crucial governance component and a critical ability determinant of government to respond effectively to climate change and $\mathrm{UHI}$, followed by the overall challenges to sustainable development [122]. As property values are associated with land uses, and climate change becomes an issue for the insurance business, this becomes an extra critical component that necessitates mitigation strategy [123]. Finally, spatial planning in tackling climate change is highlighted by the vulnerabilities to climate change and adaptation/mitigation measures that exhibit spatial characteristics [124].

\subsection{Environmental Planning}

Urban planners play essential roles in protecting and enhancing biodiversity, environmentally sensitive areas, and ecosystems. In particular, the planners can help to relocate, minimize, or prohibit developments (either planned or informal) in environmentally sensitive areas like estuaries, wetlands, and, additionally, critical coastal habitats like mangrove forests [119]. The urban environmental concerns have often been categorized as either the 'brown' or the 'green' agendas. The 'brown' agenda prioritizes public safety and addresses local issues like inadequate water and sanitation, urban air pollution, and solid waste disposal. Many of these are especially important to disadvantage urban dwellers. Inadequate water supply, sewage, and irrigation, coupled with the vast production volumes of toxic waste, air pollution, and water pollution, can significantly affect urban residents. These contaminate problems are particularly acute in low-income areas [125]. At the same time, urban practices are affecting environmental factors and everywhere in the world. Towns and communities depend on a wide variety of services beyond their regional borders (including water, food, and raw materials for production), and these can have significant environmental impacts on remote areas. Urban centers still consume vast quantities of electricity, hence are the major contributors to the 
global greenhouse gaseous emissions. This 'green' policy is significant to future generations and natural systems as it places a premium role in ecological sustainability. It addresses the degradation of resources, contributions to global environmental burdens, and other problems that mainly occurred outside the cities [126].

\subsection{Building and Site Planning}

The local land-use plans and developmental laws regulate the location, type, and scale of developments in climate hazard areas. Numerous locations and design features can be adopted and/or required to make the areas and buildings more resilient to climate impacts. For example, the living areas need to be located at a suitable height and above the flood hazard levels [119]. Moreover, the urban design can affect the energy usages and production in cities, as denser settlements reduce the energy required for transportation [127]. At the same time, the data showed that the energy savings and costs of between 20 to $50 \%$ are possible through integrated planning with carefully considered site orientations and passive strategies [128]. However, some authors identified that the urban scale had been neglected in energy consumption and climate change $[128,129]$. Although limited in numbers, these studies focused on the zoning plan layout and the urban canyon. Furthermore, the studies demonstrated that the zoning plan considerably impacts the buildings' energy use, daylight penetration, and availability of solar radia $\neg$ tion $[130,131,132]$.

\subsection{Community Health Programmes}

With acclimation to climatic change, a healthy population is more resilient. Therefore, by understanding this link and the apparent connections between the urban form and public health, the planners can significantly impact the public health programs and policies [119].

\subsection{Transportation Plans and Projects}

The transportation industry is projected to be responsible for $25 \%$ of all energy-related greenhouse gas emissions. Similarly, private cars are accounted for a significant proportion of that activity. So, the urban planners can help to mitigate greenhouse gaseous emissions by reducing the vehicle miles traveled and urban congestion through compact, high-density, mixed-use developments. Additionally, the strategically planned development can also direct the development to areas less vulnerable to the impacts of climate change [119].

\subsection{CONCLUSION}

Various research in various disciplines has emerged and has been explored to track and examine the thermal comfort in the built environment to find solutions to the high urban temperatures that impact urban living and human life. This paper also combined the projects conducted, the body of knowledge learned in numerous but closely related disciplines, and the direct future studies to assess microclimate indicators, to solve the issues due to the high urban temperatures. These efforts were performed by reviewing and monitoring the thermal environments in several scales (i.e., city, house, human) or harnessing the unattended physiological and psychological responses to thermal stresses in the cities. After determining the scientific parameters needed for the bodies portrayal of literature, 110 publications were reviewed and listed to establish (a) the emerging trends and goals of thermal comfort evaluations, (b) the history and focuses of micro-climate science, and (c) the potential criteria for monitoring thermal comfort and micro-climate in the built environments. In this comprehensive analysis, we observed that the microclimate variables evaluation focuses on three main areas. The first area is the measurement or improvement of thermal comfort in the urban environments (mainly based on the structures of buildings) using a variety of innovative methodologies (e.g., IOT, machine learning, and IR thermography). This subject area reflects the bulk of the research that measures personal thermal sensitivity but mainly focuses on the office and industrial spaces. The second area measures urban temperature and urban heat island at a more satisfactory resolution using traditional approaches and determining the urban dwellers' physical and mental health impacts. The third area is the evaluations of thermal comfort and strain that lead to occupational and recreational safety. However, this area focuses on the vulnerable groups in this region and comprises just a small fraction of the research field.

The concept of urban design is open to much interpretation due to its multidimensional nature. Different groups of people, for example, professionals, educators, researchers, the private sector, and the lay public, may have different thinking about urban design, thus bringing their own experiences to this concept. Regardless of how different the definitions are, there is agreement on the critical elements of urban design. [133]. The urban design may act as a multifaceted approach and response to urban changes and developments. Urban design principles, guidelines, and considerations are continually formulated and evolved to fulfill social, functional, aesthetical, and emotional needs. The emphasis is placed on the use, perception, and experiences with the places over time. Therefore, with this appropriate knowledge, urban design can be defined as the art and processes of designing, creating, making, and managing spaces and places for the people [134].

From this definition, two things become apparent. First, the urban design of a place is creative and unique to each situation, so it cannot be employed as a blanket policy at a national level in all places.

Instead, the urban design must be fostered at a more local level through the local authorities, the 
community, and local businesses, as these groups have more experience with dealing with the local and specific urban design issues. Thus, urban design is a fundamental part of creating sustainable communities that are lively places with distinctive characters, safe, accessible, pleasant to use, fulfilling the human scale, and inspirational [135].

As a recent approach towards sustainable urban design, the World Bank report (2018) stated that every city is unique. Thus, the essential matters for long-term sustainability are different from one city to another, and this variation also reflects the different contexts, challenges, and political priorities. However, as summarized in figure 10, a simple process can be applied within all the cities to guide decision-making and establish and implement a cost-effective sustainability agenda. This process is flexible enough to respond to the short-term needs and reveal a longterm development view [136].

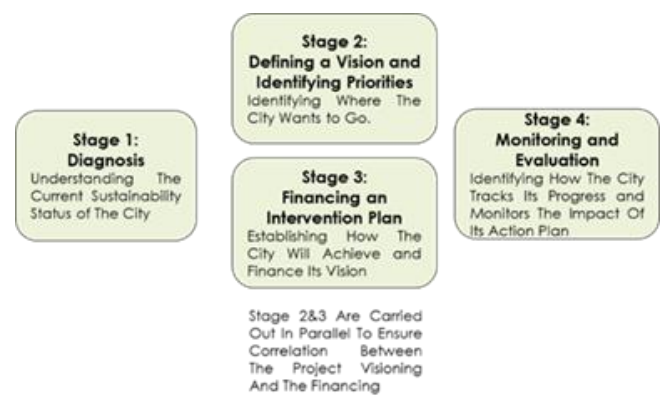

Figure 10 The Four Stages of the USF [136]

The obvious point shows that in the pursuit of balance between the present and future generations [34], it is essential to acknowledge the reality of a predominantly urban future [137]. The cities are acting as the drivers of sustainable development by applying sustainability targets. Hence, the cities are recognized "as a tool for sustainable development and climate change" [138]. Thereby, the cities present several challenges but also hold a range of opportunities. The cities are planning and pursuing fundamental changes towards more sustainable conditions by following and adopting the UN 2030 Sustainable Development Agenda and its SDGs in 2015 [139]. Hence, the world is beginning to realize that cities are dynamic places where positive changes are happening rapidly at an unprecedented rate [136]. The suggestions from the previous sections to combat climate issues in urban design clearly show that the urban design approach can provide an environment with a suitable climate and thermal comfort for its users. Most importantly, good climatic advantages can be used in the urban space with the right decisions in the urban design process and such an environment.

Unexpectedly growing metropolitan districts have been seen worldwide, according to popular belief. This increase has an immediate influence on the microclimate and, as a result, on human comfort, negatively influencing global climate and electricity consumption levels. Building more energy-efficient and sustainable urban areas to mitigate the effects of climate change is as important as anticipating living conditions in future climate scenarios that emerge, necessitating the development of new tools and methods to assist urban planners, architects, and communities in achieving this goal. In conclusion, Figure 11 shows the processes of achieving a desirable urban design pattern in the field of climatic concerns proposed by this study.

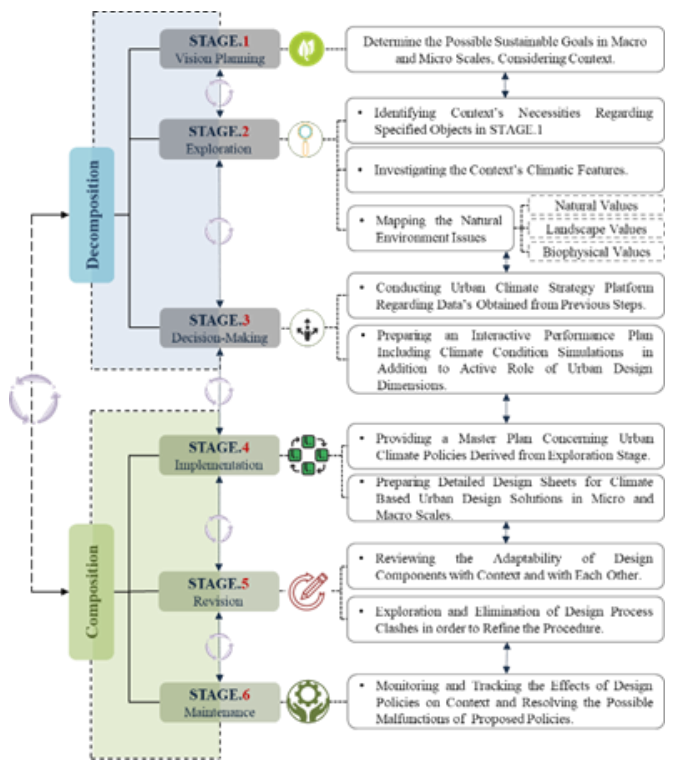

Figure 11 Climate-Based Urban Design Process

Even though urban design falls between city planning and architectural design, it is becoming the appropriate tool to overcome sustainable challenges through the ability to solve the buildings' environmental and energy deficiencies [140]. As the national, regional, and local governments continue to stress the importance of sustainability in urban design, key decision-makers and stakeholders need to become more responsible in understanding the urban design processes and the sustainability embedded [141]. Finally, the urban planning strategies for climate change mitigation should be planned in harmony with sustainable development goals while appreciating the co-benefits and considering any possible undesirable effects and risks that may arise from the implementation [140]. During the development and application of the climate change consideration plans, the municipal agencies should cooperate with civil societies, residents, and international organizations. The urban areas consist of various interconnected systems that promote effective urban planning and governance to mitigate climate change. Hence, this study describes a detailed literature classification and state-of-the-art approaches to determine the building environment's heat sensitivity and describes the main threats and future goals. The findings are as summarised in detail below: 
- The formation and advancement in thermal comfort measurement methodologies to access various sizes, flexible, economical, and technically sound testing and modeling solutions.

- The evaluation of reliable results and research standardization. The review observed a considerable lack of studies that offer a comparative accuracy evaluation, and more importantly, no metrics, recommendations, or criteria to develop a comparative evaluation of personal thermal exposures across various scales, sites, and focal groups.

- The expansion of the research to study the impacts of thermal comfort conditions on vulnerable populations. We note that the microclimate in occupational environments and the disadvantaged populations are significantly vulnerable to heat exposure. New technology and rich spatial databases need to be developed in several fields, intending to advance the research on the thermal exposure of cities and the related health consequences in urban climate.

\section{Acknowledgments}

This paper is part of a Ph.D. thesis under the supervision of Dr. Norsidah Binti Ujang at the Faculty of Design and Architecture (FRSB), Universiti Putra Malaysia (UPM).

\section{References}

[1] UNDP. 2019. United Nations Development Programme. Annual Report. New York, United States of America.

[2] IPCC. 2007. Contribution of Working Groups I, II, and III to the Fourth Assessment Report of the Intergovernmental Panel on Climate Change. Intergovernmental Panel on Climate Change. Geneva, Switzerland.

[3] White, P., Pelling, M., Sen, K., Seddon, D., Russel, S., Few, R. 2005. Disaster Risk Reduction: A Development Concern. A Scoping Study on Links between Disaster Risk Reduction, Poverty, and Development. London: Department for International Development.

[4] Bartlett, S., \& Satterthwaite, D. 2016. Cities on a Finite Planet: Towards Transformative Responses to Climate Change. Routledge.

[5] Adger, W. 2003. Social Capital, Collective Action, and Adaptation to Climate Change. Ecological Economics. 384404. DOI:10.1007/978-3-531-92258-4_19.

[6] Paris Agreement. 2015. The Paris Agreement under the United Nations Framework Convention on Climate Change (UNFCCC). Paris: United Nations.

[7] Parnell, S. 2016. Defining a Global Urban Development Agenda. World Development. 529-540. DOI:10.1016/j.worlddev.2015.10.028.

[8] World Bank. 2011. Guide to Climate Change Adaptation in Cities. World Bank.

[9] Oke, T. R. 1976. The Distinction Between Canopy and Boundary Layer Urban Heat Islands. The Atmosphere. 268277. DOI:10.1080/00046973.1976.9648422.

[10] PCC. 2013. Contribution to the IPCC Fifth Assessment Report Climate Change: The Physical Science Basis. Geneva: Intergovernmental Panel on Climate Change.

[11] IPCC. 2018. Summary for Policymakers. Masson-Delmotte, V., Zhai, P., Portner, H-O., Roberts, D., Skea, J., Shukla, P. R.,
Pirani, A., Moufouma-Okia, W., Pean, C., Pidcock, R., Connors. S., Matthews, J. B. R., Chen, Y., Zhou, X., Gomis, M. I., Lonnoy, E., MaycockTignor, M., Waterfield. T. Editors. Geneva: World Meteorological Organization.

[12] Mauree, Dasaraden \& Naboni, Emanuele \& Coccolo, Silvia \& Perera, A. T. D. \& Nik, Vahid \& Scartezzini, Jean-Lovis. 2019. A Review of Assessment Methods for the Urban Environment and Its Energy Sustainability to Guarantee Climate Adaptation of Future Cities Contribution Highlights. Renewable and Sustainable Energy Reviews. 112: 733-746. DOI: 10.1016/j.rser.2019.06.005.

[13] Muthu, S. S. Ed. 2019. Development and Quantification of Sustainability Indicators. Springer Singapore.

[14] Grin, J., Rotmans, J., Schot, J., Geels, F., Loorbach, D. 2010. Transitions to Sustainable Development. In R. J. Grin, J., Part 1. New Directions in the Study of Long-term Transformative Change. New York: Routledge

[15] Fischer, Joern \& Dyball, Robert \& Fazey, loan \& Gross, Catherine \& Dovers, Stephen \& Ehrlich, Paul \& Brulle, Robert \& Christensen, Carleton \& Borden, Richard. 2012. Human Behavior and Sustainability. Frontiers in Ecology and the Environment. 10: 153-160. DOI:10.2307/41480675.

[16] Tanguay, Georges \& Rajaonson, Juste \& Lefebvre, JeanFrançois \& Lanoie, Paul. 2010. Measuring the Sustainability of Cities: An Analysis of the Use of Local Indicators. Ecological Indicators. $\quad 407-418 . \quad$ Doi:10. 407-418. 10.1016/j.ecolind.2009.07.013.

[17] Pissourios, I. 2013. An Interdisciplinary Study on Indicators: A Comparative Review of Quality-of-life, Macroeconomic, Environmental, Welfare, and Sustainability Indicators. Ecological Indicators. 420-427. DOI: $0.1016 / j$.ecolind.2013.06.008.

[18] Turcu, C. 2013. Re-thinking Sustainability Indicators: Local Perspectives of Urban Sustainability. Journal of Environmental Planning and Management. DOI:10.1080/09640568.2012.698984

[19] Mori, K., Christodoulou, A. 2012. Review of Sustainability Indices and Indicators: Towards a New City Sustainability Index (CSI). Environmental Impact Assessment Review. 94106. DOI: 10.1016/j.eiar.2011.06.001.

[20] Pupphachai, Uma \& Zuidema, Christian. 2017. Sustainability Indicators: A Tool to Generate Learning and Adaptation in Sustainable Urban Development. Ecological Indicators. 748793. DOI: 10.1016/j.ecolind.2016.09.016.

[21] United Nations General Assembly Resolution 70/1. 2015. Transforming Our World: The 2030 Agenda for Sustainable Development, A/RES/70/1. United Nations. Retrieved from http://www.un.org/en/development/desa/population/migr ation/generalassembly/docs/globalcompact/A_RES_70_1_E. pdf.

[22] Kumar, P., Thakur, P. K., Bansod, B. K. S., Debnath, S. K. 2017. Groundwater: A Regional Resource and Regional Governance. Environment, Development, and Sustainability. 1-19. Doi:http://dx.doi.org/10.1007/s10668-017-9931-y.

[23] Griggs, D., Stafford-Smith, M., Gaffney, O., Rockström, J., Öhman, M. C., Shyamsundar. 2013. Policy: Sustainable Development Goals for People and Planet. P. Noble, I. Nature. 305-307. Doi:http://dx.doi.org/10.1038/495305a.

[24] Le Blanck, D. 2015. The Sustainable Development Goals as a Network of Targets. Monit. Eval. 1-4. Retrieved from http://www.un.org/esa/desa/papers/2015/wp141_2015.pdf.

[25] Fiala, N. 2008. Measuring Sustainability: Why the Ecological Footprint Is Bad Economics and Bad Environmental Science. Ecological Economics. 67: 519-525. Doi:10.1016/j.ecolecon.2008.07.023.

[26] United Nations. 2008. Achieving Sustainable Development and Promoting Development Cooperation: Dialogues at the Economic and Social Council. New York: United Nations Publications.

[27] Tang, Hui-Ting \& Lee, Yuh-Ming. 2016. The Making of Sustainable Urban Development: A Synthesis Framework. Sustainability. DOI: 8. 492. 10.3390/su8050492.

[28] Dizdaroglu, D. 2015. Developing Micro-level Urban Ecosystem Indicators for Sustainability Assessment. 
Environmental Impact Assessment Review. 119-124. DOI: 10.1016/j.eiar.2015.06.004.

[29] Zygiaris, S. 2013. Mart City Reference Model: Assisting Planners to Conceptualize the Building of Smart City Innovation Ecosystems. Journal of the Knowledge Economy. 217-231. DOI: http://dx.doi.org/10.1007/s13132-012-0089-4

[30] Wolch, J. R., Byrne, J., Newell, J. P. 2014. Urban Green Space, Public Health, and Environmental Justice: The Challenge of Making Cities Just Green Enough. Landscape and Urban Planning. 234-244. DOI: 10.1016/j.landurbplan.2014.01.017.

[31] Fawzi Raed Ameen, M., \& Mourshed, M. 2016. Environmental, Social, and economic challenges for Urban Development: Stakeholder's Perception in a Developing Economy. The 16th International Conference on Computing in Civil and Building Engineering. Proceedings.

[32] Shen, L., Guo, X. 2014. Spatial Quantification and Pattern Analysis of Urban Sustainability on a Subjectively Weighted Indicator Model: A Case Study in Saskatoon, S. K., Canada. Applied Geography. 117-127. DOl: http://dx.doi.org/10.1016/j. apgeog.2014.06.001.

[33] Verma, Pramit \& Raghubanshi, Akhilesh. 2018. Urban Sustainability Indicators: Challenges and Opportunities. Ecological Indicators. 282-291. DOl: 10.1016/j.ecolind.2018.05.007.

[34] WCED. 1987. Our Common Future. World Commission on Environment and Development. Oxford University Press.

[35] Vezzoli, C. 2018. Design for Environmental Sustainability. Springer. DOI: 10.1007/978-1-4471-7364-9.

[36] Baynes, Timothy \& Wiedmann, Thomas. 2012. General Approaches for Assessing Urban Environmental Sustainability. Current Opinion in Environmental Sustainability. 458-464. DOI: 10.1016/j.cosust.2012.09.003.

[37] Song, Y. 2011. Ecological City and Urban Sustainable Development. Procedia Engineering. 142-146. DOI: 10.1016/j.proeng.2011.11.1997.

[38] Spirn, A. 2014. Ecological Urbanism: A Framework for the Design of Resilient Cities. In F. O. Ndubisi, the Ecological Design and Planning Reader. Island Press. 557-567.

[39] Young, R., Zanders, J., Lieberknecht, K., Fassman-Beck, E. 2014. A Comprehensive Typology for Mainstreaming Urban Green Infrastructure. Journal of Hydrology. 2571-2583. DOI: http://dx.doi.org/10.1016/j.jhydrol.2014.05.048.

[40] Calfapietra, Carlo \& Penuelas, Josep \& Niinemets, Ülo. 2014. Urban Plant Physiology: Adaptation-mitigation Strategies Under Permanent Stress. Trends in Plant Science. 72-75. DOI: 10.1016/j.tplants.2014.11.001.

[41] Connop, S., Vandergert, P., Eisenberg, B., Collier, M. J., Nash, C., Clough, J., Newport, D. 2016. Renaturing Cities Using a Regionally-focused Biodiversity-led Multifunctional. Environmental Science and Policy. 1-13. DOI: http://dx.doi.org/10.1016/j.envsci.2016.01.013.

[42] Bennett, Elena \& Cramer, Wolfgang \& Begossi, Alpina \& Cundill, Georgina \& Diaz, Sandra et al. 2015. Linking Biodiversity, Ecosystem Services, and Human Wellbeing: Three Challenges for Designing Research for Sustainability. Current Opinion in Environmental Sustainability. 76-85. DOI: 10.1016/j.cosust.2015.03.007.

[43] Cohen-Shacham, E., Walters, G., Janzen, C., Maginnis, S. 2016. Nature-based Solutions to Address Global Societal Challenges. IUCN Commission on Ecosystem Management (CEM) and the IUCN World Commission on Protected Areas (WCPA). Switzerland.

[44] Raymond, Christopher \& Frantzeskaki, Niki \& Kabisch, Nadja \& Berry, P. \& Breil, Margaretha \& Nita, Mihai \& Geneletti, Davide \& Calfapietra, Carlo. 2017. A Framework for Assessing and Implementing the Co-benefits of Naturebased Solutions in Urban Areas. Environmental Science \& Policy. 15-24. DOI: 10.1016/j.envsci.2017.07.008.

[45] Baró, F., Haase, D., Gómez-Baggethun, E., Frantzeskaki, N. 2015. Mismatches between Ecosystem Services Supply and Demand in Urban Areas: A Quantitative Assessment in Five European Cities. Ecological Indicators. 146-158. DOI: 10.1016/j.ecolind.2015.03.013
[46] Mouchet, Maud \& Paracchini, Maria-Luisa \& Schulp, Catharina \& Stürck, J. \& Verkerk, Hans \& Verburg, Peter \& Lavorel, Sandra. 2017. Bundles of Ecosystem (Dis)Services and Multifunctionality Across European Landscapes. Ecological Indicators. 23-28. DOI: 10.1016/j.ecolind.2016.09.026.

[47] Pascual, Unai et al. 2017. Valuing Nature's Contributions to People: The IPBES Approach. Current Opinion in Environmental Sustainability. 26-27. DOI: 10.1016/j.cosust.2016.12.006.

[48] Maes et al. 2013. Mapping and Assessment of Ecosystems and Their Services. An Analytical Framework for Ecosystem Assessments Under Action 5 of the EU Biodiversity Strategy to 2020. Paris: Paris Climate Change Protection Plan.

[49] Ürge-Vorsatz, D., Herrero, S. T., Dubash, N. K., Lecocq, F. 2014. Measuring the Co-benefits of Climate Change Mitigation. Annual Review of Environment and Resources. 39: 549-582. DOI: $\quad \mathrm{http}: / / \mathrm{dx}$.doi.org/10.1146/annurev-environ-031312125456.

[50] Ouwma, Irene \& Schleyer, Christian \& Primmer, Eeva \& Winkler, Klara \& Berry, P. \& Young, Juliette \& Carmen, Esther \& Spulerova, Jana \& Bezák, Peter \& Preda, Elena \& Vadineanu, Angheluta. 2017. Adoption of the Ecosystem Services Concept in EU Policies. Ecosystem Services. DOI: 10.1016/j.ecoser.2017.02.014.

[51] Bell, S. 2012. DPSIR = A Problem Structuring Method? An Exploration from the "Imagine" Approach. European Journal of Operational Research. 350-360. DOI: 10.1016/j.ejor.2012.04.029.

[52] Spencer, Benjamin \& Lawler, Josh \& Lowe, Celia \& Thompson, Luanne \& Hinckley, Tom \& Kim, Soo-Hyung \& Bolton, Susan \& Meschke, Scott \& Olden, Julian \& Voss, Joachim. 2016. Case Studies in the Co-benefits Approach to Climate Change Mitigation and Adaptation. Journal of Environmental Planning and Management. 1-21. DOI:10.1080/09640568.2016.1168287.

[53] Palazzo, Elisa \& Wan Mohd Rani, Wan. 2017. Regenerating Urban Areas Through Climate Sensitive Urban Design. Advanced Science Letters. 6394-6398. DOI:10.1166/asl.2017.9277.

[54] Watson, V. 2009. The Planned City Sweeps the Poor Away...': Urban Planning and 21 st-century Urbanization. Progress in Planning. 151-193. DOI: 10.1016/j.progress.2009.06.002.

[55] UNEP/UNHABITAT. 2005. Cities and Climate Change. Earthscan.

[56] Oke, T., Mills, G., Christen, A., \& Voogt, J. 2017. ClimateSensitive Design. In Urban Climates Cambridge: Cambridge University Press. 408-452. DOI: 10.1017/9781139016476.016

[57] Berger, M. 2014. The Unsustainable City. Sustainability. 365374. DOI: 10.3390/su6010365

[58] Da Silva, Jo \& Kernaghan, Sam \& Luque, Andres. 2012. A Systems Approach to Meeting the Challenges of Urban Climate Change. International Journal of Urban Sustainable Development. DOI: 4. 10.1080/19463138.2012.718279.

[59] Satterthwaite, D., Huq, S., Pelling, M., Reid, A., RomeroLankao, P. 2007. Adapting to Climate Change in Urban Areas: The Possibilities and Constraints in Low- and Middle-income Nations. London: Human Settlements Discussion Paper Series Climate Change and Cities.

[60] Intergovernmental Panel on Climate Change. 2007. Climate Change 2007: Synthesis Report. Geneva: UN-IPCC.

[61] Carter, Jeremy \& Cavan, Gina \& Connelly, Angela \& Guy, Simon \& Handley, John \& Kazmierczak, Aleksandra. 2014 Climate Change and the City: Building Capacity for Urban Adaptation. Progress in Planning. 95: 1-66. DOI: 10.1016/j.progress.2013.08.001

[62] Gill, Susannah \& Handley, J. F. \& Ennos, Roland \& Pauleit, Stephan. 2007. Adapting Cities for Climate Change: The Role of the Green Infrastructure. Built Environment. 33: 115-133. DOI: 10.2148/benv.33.1.115

[63] Smith, Claire \& Lindley, Sarah \& Levermore, G. 2009. Estimating Spatial and Temporal Patterns of Urban Anthropogenic Heat Fluxes for UK Cities: The Case of 
Manchester. Theoretical and Applied Climatology. 98: 19-35. DOI: 10.1007/s00704-008-0086-5.

[64] 100 Resilient Cities. 2016. 100 Resilient Cities. Retrieved from http://www.100resilientcities.org.

[65] Pozzi, Matteo \& Memarzadeh, Milad \& Klima, Kelly. 2017. Hidden-model Processes for Adaptive Management under Uncertain Climate Change. Journal of Infrastructure Systems. 23. DOI: 10.1061/(ASCE)IS.1943-555X.0000376.

[66] Markolf, Samuel \& Klima, Kelly \& Wong, Terrence. 2015. Adaptation Frameworks Used by US Decision-makers: A Literature Review. Environment, Systems, and Decisions. 35: 427-436. DOI: 10.1007/s10669-015-9572-3.

[67] Hughes, Sara \& Sarzynski, Andrea. 2015. Building Capacity for Climate Change Adaptation in Urban Areas: Editors' Introduction. Urban Climate. 14: 1-3. DOI: 10.1016/j.uclim.2015.07.002.

[68] Lesnikowski, Alexandra \& Ford, James \& Biesbroek, Robbert \& Berrang-Ford, Lea \& Heymann, S. 2016. National-level Progress on Adaptation. Nature Climate Change. 6: 261-264. DOI: 10.1038/nclimate2863.

[69] Alberti, M. 2007. Advances in Urban Ecology: Integrating Humans and Ecological Processes in Urban Ecosystems. New York: Springer.

[70] Grimm, Nancy \& Grove, Morgan \& Pickett, S. T. A. \& Redman, Charles. 2008. Integrated Approaches to LongTerm Studies of Urban Ecological Systems. In N. \&. Grimm, Urban Ecology. 123-141.

[71] Pickett, Steward T. A., Mary L. Cadenasso, J. Morgan Grove, Christopher G. Boone, Peter M. 2011. Urban Ecological Systems: Scientific Foundations and a Decade of Progress. Journal of Environmental Management. 331-362. DOI: 10.1016/j.jenvman.2010.08.022.

[72] Gaston, K. 2010. Urban Ecology (Ecological Reviews). Cambridge: Cambridge University Press. DOI: 10.1017/CBO9780511778483.

[73] Myrna H. P. Hall. 2019. Understanding Urban Ecology: An Interdisciplinary Systems Approach. Switzerland: Springer International Publishing.

[74] Alan R. Berkowitz, Charles H. Nilon, Karen S. Hollweg. 2002. Understanding Urban Ecosystems: A New Frontier for Science and Education. Springer-Verlag New York: New York. DOI: 10.1007/b97613.

[75] Mayer, H. 1989. Ideales Stadtklima' on 26 Oktober 1988 in Munich. German Meteor. Munich: German Meteorological Society.

[76] Amado, Miguel \& Poggi, Francesca. 2012. Towards Solar Urban Planning: A New Step for Better Energy Performance. Energy Procedia. 1261-1273. DOI: 10.1016/j.egypro.2012.11.139.

[77] Musco, F. 2016. Counteracting Urban Heat Island Effects in a Global Climate Change Scenario. Springer, Cham. DOI: https://doi.org/10.1007/978-3-319-10425-6.

[78] Monsefi Parapari, D. 2015. Adaptation to Climate Change and Thermal Comfort; Investigating Adaptation and Mitigation Strategies for Kerman, Iran, Based on Traditional Iranian Urbanism and the German Experiences in the Ruhr. Dortmund, Germany. Doctoral Dissertation.

[79] Johansson, Erik \& Emmanuel, R. 2006. The Influence of Urban Design on Outdoor Thermal Comfort in the Hot, Humid City of Colombo, Sri Lanka. International Journal of Biometeorology. 51: 119-33. DOI: 10.1007/s00484-006-0047-6.

[80] Blazejczyk, Krzysztof, Yoram Epstein, Gerd Jendritzky, Henning Staiger and Birger. 2012. Comparison of UTCl to Selected Thermal Indices. International Journal of Biometeorology. 56(3): 515-535.

[81] Höppe, P. 1999. The Physiological Equivalent Temperature-A Universal Index for the Biometeorological Assessment of the Thermal Environment. International Journal of Biometeorology. 43: 71-75. DOI: 10.1007/s004840050118.

[82] Pickup, J., de Dear, R. 2000. An Outdoor Thermal Comfort Index (OUT_SET*)-Part 1- The Model and Its Assumptions. Proceedings of the 15th International Congress Biometeorology and International Conference on Urban Climatology. Sydney.
[83] Cheng, V., Ng, E., Chan, C., Givoni, B. 2012. Outdoor Therma Comfort Study in a Sub-tropical Climate: A Longitudinal Study based in Hong Kong. International Journal of Biometeorology. 56: 43-56. DOI: 10.1007/s00484-010-0396-z

[84] de Freitas, C. R. 1985. Assessment of Human Bioclimate based on Thermal Response. International Journal of Biometeorology. 29: 97-119. DOI:10.1007/BF02189029.

[85] Gagge, A. P. \& Fobelets, A. P. \& Berglund, L. 1986. A Standard Predictive Index of Human Response to the Thermal Environment. ASHRAE Transactions. 92.

[86] Johansson, E., Thorsson, S., Emmanuel, R., Krüger, E. 2014. Instruments and Methods in Outdoor Thermal Comfort Studies-The Need for Standardization. Urban Climate. 10: 346-366. DOI: 10.1016/j.uclim.2013.12.002.

[87] De Freitas, C. R., Grigorieva, E. A. 2015. A Comprehensive Catalog and 662 Classifications of Human Thermal Climate Indices. International Journal of Biometeorology. 59: 109-120. DOI: 10.1007/s00484-014-0819-3.

[88] Coccolo, S., Kämpf, J., Scartezzini, J.-L., Pearlmutter, D. 2016. Outdoor Human Comfort and Thermal Stress: A Comprehensive Review on Models and Standards. Urban Climate. 18: 33-57. DOI: 10.1016/j.uclim.2016.08.004.

[89] ISO 10551. 1995. Ergonomics of the Thermal Environment Assessment of the Influence of the Thermal Environment Using Subjective Judgement Scales. Geneva: International Organization for Standardization.

[90] ANSI/ASHRAE. 2004. Thermal Environment Conditions for Human Occupancy.

[91] Djongyang, N., Tchinda, R., \& Njomo, D. 2010. Thermal Comfort: A Review Paper. Renewable and Sustainable Energy Reviews. 14: 2626-2640. DOI: https://doi.org/10.1016/j.rser.2010.07.040.

[92] Ebrahimabadi, Saeed \& Johansson, Charlotta \& Rizzo, Agatino \& Nilsson, Kristina. 2016. Microclimate Assessment Method for Urban Design - A Case Study in a Subarctic Climate. Urban Design International. 23. DOI: 10.1057/udi.2015.26.

[93] Eliasson, Ingegärd \& Knez, Igor \& Westerberg, Ulla \& Thorsson, Sofia \& Lindberg, Fredrik. 2007. Climate and Behaviour in a Nordic City. Landscape and Urban Planning. 82: 72-84. DOI: 10.1016/j.landurbplan.2007.01.020.

[94] Nikolopoulou, Marialena \& Steemers, Koen. 2003. Thermal Comfort and Psychological Adaptation as a Guide for Designing Urban Spaces. Energy and Buildings. 35: 95-101. DOI: 10.1016/S0378-7788(02)00084-1.

[95] Ebrahimabadi, Saeed \& Nilsson, Kristina \& Johansson Charlotta. 2015. The Problems of Addressing Microclimate Factors in Urban Planning of the Subarctic Regions. Environment and Planning B: Planning and Design. DOI: 10.1068/b130117p.

[96] Kariminia, Shahab \& Ahmad, Sabarinah. 2014. Microclimatic Conditions of an Urban Square: Role of Built Environment and Geometry. Procedia - Social and Behavioral Sciences. Seoul.

[97] Shahrestani, Mehdi \& Yao, Runming \& Luo, Zhiwen \& Turkbeyler, Erdal \& Davies, Hywel. 2014. A Field Study of Urban Microclimates in London. Renewable Energy. 73. DOI: 10.1016/j.renene.2014.05.061.

[98] Al-Kurdi, N. \& Awadallah, Tala. 2015. Role of Street-Level Outdoor Thermal Comfort in Minimizing Urban Heat Island Effect by Using Simulation Program, Envi-Met: Case of Amman, Jordan. Research Journal of Environmental and Earth Sciences. 7: 42-49. DOI: 10.19026/riees.7.1694.

[99] Jamei, Elmira \& Rajagopalan, Priyadarsini. 2015. Urban Growth and Pedestrian Thermal Comfort. 49th International Conference of the Architectural Science Association. Melbourne, Australia.

[100] Zabeti, Milad \& Van Dessel, Steven. 2015. Potential Contribution of Urban Developments to Outdoor Thermal Comfort Conditions: The Influence of Urban Geometry and Form in Worcester, Massachusetts, USA. Procedia Engineering. 118: 1153-1161. DOI: 10.1016/j.proeng.2015.08.457. 
[101] Bassolino, Eduardo \& Ambrosini, Luciano. 2016. Parametric Environmental Climate Adaptive Design: The Role of Data Design to Control Urban Regeneration Project of Borgo Antignano, Naples. Procedia - Social and Behavioral Sciences. 216. DOI: 10.1016/j.sbspro.2015.12.092.

[102] Gusson, Carolina \& Duarte, Denise. 2016. Effects of Built Density and Urban Morphology on Urban Microclimate Calibration of the Model ENVI-met V4 for the Subtropical Sao Paulo, Brazil. 4th International Conference on Countermeasures to Urban Heat Island: Singapore.

[103] Horrison, E. \& Amirtham, Lilly. 2016. Role of Built Environment on Factors Affecting Outdoor Thermal Comfort - A Case of T. Nagar, Chennai, India. Indian Journal of Science and Technology. 9. DOI: 10.17485/ijst/2016/v9i5/87253.

[104] Xin, Lai \& Yang, Tang \& li, Lei \& PakWai, Chan \& Qingfeng, Zeng. 2018. Study on Microclimate Observation Network for Urban Unit: A Case Study in a Campus of Shenzhen, China. Physics and Chemistry of the Earth, Parts A/B/C. 110. DOI: 10.1016/j.pce.2018.08.003.

[105] Toparlar, Y. \& Blocken, B. \& Maiheu, Bino \& van Heijst, Gertjan. 2018. Impact of Urban Microclimate on Summertime Building Cooling Demand: A Parametric Analysis for Antwerp, Belgium. Applied Energy. 228: 852-872. DOI: 10.1016/j.apenergy.2018.06.110.

[106] Peng, You \& Feng, Tao \& Timmermans, Harry. 2019. A Path Analysis of Outdoor Comfort in Urban Public Spaces. Building and Environment. 148: 459-467. DOI: 10.1016/j.buildenv.2018.11.023.

[107] Fatih Canan, Iacopo Golasi, Virgilio Ciancio, Massimo Coppi, Ferdinando Salata. 2019. Outdoor Thermal Comfort Conditions during Summer in a Cold Semi-arid Climate. A Transversal Field Survey in Central Anatolia (Turkey). Building and Environment. 148: 212-224. DOI: https://doi.org/10.1016/j.buildenv.2018.11.008.

[108] Othman, Nurnida \& Shaikh Salim, sheikh Ahmad Zaki \& Rijal, Hom \& Ahmad, Nurul \& Abd Razak, Azli. 2021. Field Study of Pedestrians' Comfort Temperatures under Outdoor and Semi-outdoor Conditions in Malaysian University Campuses. International Journal of Biometeorology. 65. 10.1007/s00484020-02035-3.

[109] Shaikh Salim, Sheikh Ahmad Zaki \& Syahidah, Siti \& Shahidan, Mohd \& Ahmad, Mardiana \& Yakub, Fitri \& Hassan, Mohamad \& Md Daud, Mohd Yusof. 2020. Assessment of Outdoor Air Temperature with Different Shaded Area within an Urban University Campus in Hot-Humid Climate. Sustainability. 12.5741. 10.3390/sul2145741.

[110] Shaikh Salim, Sheikh Ahmad Zaki \& Othman, Nurnida \& Syahidah, Siti \& Yakub, Fitri \& Muhammad-Sukki, Firdaus \& Ardila-Rey, Jorge \& Shahidan, Mohd \& Mohd Saudi, Ahmad Shakir. 2020. Effects of Urban Morphology on Microclimate Parameters in an Urban University Campus. Sustainability. 12. 2962. 10.3390/sul2072962.

[1 11 1] Nikolopoulou, M. 2011 . Outdoor Thermal Comfort. Frontiers in Bioscience. 1552-68. DOI: 10.2741/245.

[1 12] Walton, Darren \& Dravitzki, V. \& Donn, Michael. 2007. The Relative Influence of Wind, Sunlight, and Temperature on User Comfort in Urban Outdoor Spaces. Building and $\begin{array}{llll} & \text { Environment. } & \text { 42: } & \end{array}$ 10.1016/j.buildenv.2006.08.004.

[113] Andris Auliciems, Steven V. Szokolay. 2007. Thermal Comfort, Australia: Passive and Low Energy Architecture International (PLEA) in Association with the Department of Architecture. The University of Queensland.

[114] Givoni, B. 1992. Comfort, Climate Analysis, and Building Design Guidelines. Energy and Buildings. 18: 11-23. DOI: 10.1016/0378-7788(92)90047-K

[115] Rosenzweig C., W. Solecki, P. Romero-Lankao, S. Mehrotra, S. Dhakal, T. Bowman, and S. Ali Ibrahim. 2018. Urban Climate Change Research Network (UCCRN). Cambridge University Press.

[116] Dean, B., Dulac, J., Petrichenko, K., \& Graham, P. (2016). Towards zero-emission efficient and resilient buildings. Global Status Report. Global Alliance for Buildings and Construction (GABC).
[117] Cheshmehzangi, Ali \& Dawodu, Ayotunde. (2018). Sustainable Urban Development in the Age of Climate Change. Springer Verlag.

[118] Erell, E. (2008). The Application of Urban Climate Research in the Design of Cities. Advances in Building Energy Research, 95-121. DOI:10.3763/aber.2008.0204

[119] UNHabitat. (2014). Planning for Climate Change. UNON, Publishing Services Section,

[120] Wie, E. $(2016,5,17)$. IN A CHANGING CLIMATE, LAND USE PLANNING FOR THE URBAN BILLIONS. Retrieved from Yale School of Forestry \& Environmental Studies: https://environment.yale.edu/blog/2016/05/urban-land-useplanning-climate/

[121] Cashmore, Matthew \& Wejs, Anja. (2013). Constructing legitimacy for climate change planning: A study of local government in Denmark. Global Environmental Change, 24, 203-212. DOI: 10.1016/j.gloenvcha.2013.09.019.

[122] Yiannakou, Athena \& Salata, Konstantina. (2017). Adaptation to Climate Change through Spatial Planning in Compact Urban Areas: A Case Study in the City of Thessaloniki. Sustainability, 9. DOI:10.3390/su9020271.

[123] Blakely, E. (2007). Urban Planning for Climate Change. Lincoln Institute of Land Policy.

[124] Wandl, Alexander \& van der Hoeven, Frank. (2014). Amsterdam: Mapping the land use, health, and energyefficiency implications of the Amsterdam urban heat island. Building Services Engineering Research and Technology, 36. DOI:10.1177/0143624414541451.

[125] UNEP. (2013). INTEGRATING THE ENVIRONMENT IN URBAN PLANNING AND MANAGEMENT. UNON/Publishing Section Services.

[126] McGranahan G, Satterthwaite D. (2000). Environmental Health or Ecological Sustainability? Reconciling the Brown and Green Agendas in Urban Development' in Pugh. London: Earthscan.

[127] Hestnes, A. G. (1999). Building Integration of Solar Energy Systems. Solar Energy, 67, 181-187.

[128] Lehmann, S. (2008). Sustainability on the Urban Scale: Green Urbanism-New Models for Urban Growth and Neighbourhoods. In D. Peter, Urban Energy Transition (pp. 409-430). Elsevier.

[129] Ratti, C., Baker, N., \& Steemers, K. (2005). Energy consumption and urban texture. Energy and Buildings, 37, 762-776. DOI: 10.1016/j.enbuild.2004.10.010.

[130] Cheng, Vicky \& Steemers, Koen \& Montavon, M. \& Compagnon, Raphaël. (2006). Urban Form, Density, and Solar Potential. Paper presented at the PLEA Geneva. Geneva.

[131] Van Esch, M. M. E., Looman, R. H. J., \& de Bruin-Hordijk, G. J. (2012). The effects of urban and building design parameters on solar access to the urban canyon and the potential for direct passive solar heating strategies. Energy and Buildings, 47, 189-200. DOI: 10.1016/j.enbuild.2011.11.042

[132] Strømann-Andersen, J., \& Sattrup, P. A. (2011). The urban canyon and building energy use: Urban density versus daylight and passive solar gains. Energy and Buildings, 43 2011-2020. DOI: https://doi.org/10.1016/j.enbuild.2011.04.007

[133] Davey, Caroline \& Cooper, Rachel \& Boyko, Christopher. (2005). Sustainability and the urban design process. Proceedings of The Institution of Civil Engineers-engineering Sustainability, $\quad 158, \quad$ pp. 119-125. DOI:10.1680/ensu.2005.158.3.119.

[134] Rowley, A. (1994). Definitions of urban design: the nature and concerns of urban design. Planning Practice and Research, 3, 179-198. DOI:10.1080/02697459408722929

[135] Commission for Architecture and the Built Environment. (2001). By Design: Urban Design in the Planning System. London: Commission for Architecture and the Built Environment.

[136] World Bank. 2018. Urban Sustainability Framework (USF). Washington, DC: World Bank.

[137] Barnett, Clive \& Parnell, Susan. 2016. Ideas, Implementation, and Indicators: Epistemologies of the Post-2015 Urban 
Agenda. Environment and Urbanization. 28. DOI: $10.1177 / 0956247815621473$.

[138] McCormick, Kes \& Anderberg, Stefan \& Coenen, Lars \& Neij, Lena. 2013. Advancing Sustainable Urban Transformation. Journal of Cleaner Production. 50: 1-11. DOI: 10.1016/j.jclepro.2013.01.003.

[139] United Nations General Assembly Resolution 70/1. 2015. Transforming Our World: The 2030 Agenda for Sustainable Development, A/RES/70/1. United Nations. Retrieved from http://www.un.org/en/development/desa/population/migr ation/generalassembly/docs/globalcompact/A_RES_70_1_E. pdf.

[140] Giovagnorio, llaria \& Chiri, Giovanni. 2016. The Environmental Dimension of Urban Design: A Point of View. In I. \&. Giovagnorio, Sustainable Urbanization. 37-60. DOI: $10.5772 / 62883$.

[141] Urge-Vorsatz, D., Rosenzweig, C., Dawson, R. J., Rodriguez, R. S., Bai, X., Barau, A. S., et al. 2018. Locking in Positive Climate Responses in Cities. Nature Climate Change. 8. DOI: 10.1038/s41558-018-0100-6.

[142] Tumini, Irina \& Higueras Garcia, Ester \& Rada, Sergio. 2016. Urban Microclimate and Thermal Comfort Modeling: Strategies for Urban Renovation. International Journal of Sustainable Building Technology and Urban Development. 7: 1-16. 10.1080/2093761X.2016.1152204.
[143] Santamouris, Mat \& Papanikolaou, N. \& Livada, I. \& Koronaki, I. P. \& Georgakis, C. \& Argiriou, A. \& Asimakopoulos, D. 2001. On the Impact of Urban Climate on the Energy Consumption of Building. Solar Energy. 70: 201-216. 10.1016/S0038-092X(00)00095-5.

[144] Akbari, Hashem \& Pomerantz, Melvin \& Taha, H. 2001. Cool Surfaces and Shade Trees to Reduce Energy Use and Improve Air Quality in Urban Areas. Solar Energy. 70: 295-310. 10.1016/S0038-092X(00)00089-X.

[145] Mirzaei, Parham \& Haghighat, Fariborz. 2010. Approaches to Study Urban Heat Island - Abilities and Limitations. Building and Environment. 45: 2192-2201. 10.1016/j.buildenv.2010.04.001.

[146] Davies, Mike \& Steadman, Philip \& Oreszczyn, Tadj. 2008. Strategies for the Modification of the Urban Climate and the Consequent Impact on Building Energy Use. Energy Policy. 36. 4548-4551. 10.1016/j.enpol.2008.09.013.

[147] Iyendot, Jnr., Timothy \& Akingbaso, Ebunoluwa \& Alibaba, Halil \& Özdeniz, Mesut. 2016. A Relative Study of Microclimate Responsive Design Approaches to Buildings in Cypriot Settlements. 13: 69-81. 10.5505/itujfa.2016.51423.

[148] IPCC. 2021. Climate Change 2021: The Physical Science Basis the Sixth Assessment Report of the Intergovernmental Panel on Climate Change. Intergovernmental Panel on Climate Change. Geneva, Switzerland. 